\title{
Comparison of Wood and Non-Wood Market Pulps for Tissue Paper Application
}

\author{
Tiago de Assis, ${ }^{\mathrm{a}}$ Joel Pawlak, ${ }^{\mathrm{a}}$ Lokendra Pal, ${ }^{\mathrm{a}}$ Hasan Jameel, ${ }^{\mathrm{a}}$ Richard Venditti, \\ Lee W. Reisinger, ${ }^{\mathrm{b}}$ Dale Kavalew, ${ }^{\mathrm{c}}$ and Ronalds W. Gonzalez ${ }^{\mathrm{a}, *}$
}

\begin{abstract}
A comparison among ten market pulps at a laboratory scale using uncreped tissue handsheets was performed to study the performance of wood and non-wood pulps for tissue manufacturing, evaluate what fiber features are desired for a specific tissue property, and determine how non-wood pulps can be used to replace or complement wood pulps in tissue products. A characterization of the fiber morphology and handsheet properties (softness, water absorbency, and strength) was performed at different mechanical refining levels. The results showed that the fiber morphology had a major impact on tissue properties. Market pulps with a combination of long fibers, high coarseness, and low fines content can provide superior bulk and water absorbency. Short fibers with thin cell walls and low fines content can impart superior softness. Bleached bamboo soda pulp can replace hardwood and softwood pulps to provide an excellent combination of water absorbency and strength. Bleached bamboo soda pulp can also replace Northern bleached softwood kraft (NBSK) pulp to impart strength without sacrificing softness. Bleached and semi-bleached wheat straw soda pulps presented a similar combination of softness and strength as Southern bleached hardwood kraft (SBHK) pulp. The wheat straw pulps can be used to replace deinked pulp (DIP) pulp to impart intermediate levels of water absorbency and strength.
\end{abstract}

Keywords: Tissue paper; Softness; Water absorbency; Tensile strength; Fiber morphology; Hardwood pulp; Softwood pulp; Recycled pulp Non-wood pulp; Bamboo; Wheat straw

Contact Information: a: Tissue Pack Innovation Lab, Department of Forest Biomaterials Science and Engineering, Box 8005, North Carolina State University, Raleigh, NC 27695-8005, USA; b: ReiTech Incorporated, 26 The Point, Coronado, CA, 92118, USA; c: Dale Kavalew and Associates LLC, Cincinnati, OH, 45202, USA; *Corresponding author: rwgonzal@ncsu.edu

\section{INTRODUCTION}

The tissue paper industry is a well established and global business that has experienced constant growth over the last ten years (2.6\% average annual growth rate) (Euromonitor 2017; FAO 2017). Despite the optimistic scenario for market growth, the tissue paper industry has faced some profitability challenges. The intense competition among tissue paper manufacturers, constant evolution of product performance, consumer preference, increase in market pulp price, and a well-known decrease in the availability of recycled paper have contributed to decreased profitability (Essity 2017; Euromonitor 2017; Terlep 2018). In this context, it is important for tissue paper manufacturers to find alternatives (e.g., fibers, technology, additives, and new offerings) to increase the value of tissue paper products, while maintaining or reducing the manufacturing costs.

In a previous publication (de Assis et al. 2018a), the relationship between the price and performance of kitchen paper towels in the USA market was assessed to evaluate (i) 
what product features (e.g., strength, softness, water absorbency, and sustainability label) are driving shelf prices, (ii) the relationship between the product performance and product price, and (iii) what variables (e.g., technology and fiber) could be changed to improve the product value. In the present study, a complete characterization and value assessment for different types of wood and non-wood pulps in tissue manufacturing was performed to describe opportunities to better capture the product price on the market shelf and improve the flexibility of the fiber supply chain to reduce fiber sourcing costs.

The tissue paper industry in the United States typically relies on a few fiber sources. According to Fisher International (2018), 78\% of the total fiber used by the tissue industry corresponds to only four different fiber sources (sorted office paper $=\sim 29 \%$; eucalyptus $=$ $\sim 18 \%$; northern softwood $=\sim 16 \%$; and southern softwood $=\sim 15 \%$ ). The lack of flexibility in fiber sourcing makes the United States tissue industry vulnerable to global market effects. In this context, it is of great value for tissue manufacturers to develop alternative fiber sources, such as non-wood pulps, that could replace or complement the fibers currently used for tissue manufacturing. The development of alternative fibers might contribute to not only the protection of the manufacturing costs, but could also be the link to sustainability and the use of local fibers, which could connect consumer preference to sustainability and premium prices (de Assis et al. 2018a). To understand the potential for the utilization of alternative fibers in tissue paper products, it is essential to execute performance and techno-economic analysis. The focus of this study was to compare the effect of several market pulps on tissue paper properties.

Qualitative discussions about the effect of different cellulosic pulps (e.g., hardwood, softwood, and non-wood pulps) and pulping processes (e.g., kraft, sulfite, and mechanical processes) on tissue properties (e.g., softness, water absorbency, and strength) have been addressed in many publications (Hall 1983; Norwegian Pulp and Paper Research Institue 1983; Siewert 1988; Axelsson 2001; Foelkel 2007; Byrd and Hurter 2013; Tutuş et al. 2017; Zou 2017a). Quantitative analyses have also been found in the literature. Sundholm and Huostila (1980) and Yuan et al. (2016) performed a quantitative analysis to evaluate the effect of high yield pulps on the bulk, water absorbency, strength, and softness. Muller and Teufel (1973) and Zou (2017b) compared the effects of hardwood, softwood, and recycled pulps on the bulk, water absorbency, and strength. Kullander et al. (2012) and Gigac and Fišerová (2008) made pulps with a single wood species (e.g., eucalyptus, pine, spruce, and birch) using different pulping and bleaching strategies (e.g., kraft, sulfite, elemental chlorine free bleaching, and total chlorine free bleaching) and studied their effects on softness, water absorbency, and strength. Few studies have compared the performances of wood and non-wood pulps for tissue manufacturing. Zou and Liu (2016) and Goel et al. (2000) compared the effect of reed, soda wheat straw, organosolv wheat straw, hardwood, and softwood pulps on the tensile strength. Therefore, as far as the authors could ascertain, a comparison of wood and non-wood pulp performances for tissue paper application has not been fully reported, and in particular there has not been a simultaneous evaluation of all of the major tissue paper properties (strength, softness, and water absorbency).

In this context, the objective of this study was to compare the performances of commonly used wood pulps in tissue manufacturing and alternative non-wood pulps to evaluate their suitability for product applications (e.g., product type and product grade) and potential wood pulp substitution. An additional goal was to evaluate what fiber features are desired for a specific tissue property. To address this objective, a complete characterization of the fiber morphology and handsheet properties (softness, water absorbency, and 
strength) was performed for different types of wood and non-wood pulps. Additionally, PFI refining was used to evaluate the effect of different refining levels on the tissue properties.

\section{EXPERIMENTAL}

\section{Market Pulps}

Ten cellulosic pulps were evaluated, including hardwood, softwood, recycled, and non-wood pulps (Table 1). The hardwood, softwood, non-wood, and deinked pulps (DIP) were acquired from different market pulp manufacturers, whose identities were kept confidential.

Table 1. Hardwood, Softwood, Recycled, and Non-wood Pulps.

\begin{tabular}{|c|c|c|c|}
\hline Pulp Type & Pulp Name & Pulp ID & ISO Brightness \\
\hline \multirow{4}{*}{ Hardwood } & Bleached Eucalyptus Kraft & BEK & 87 \\
\cline { 2 - 4 } & Bleached Acacia Kraft & Acacia & 89 \\
\cline { 2 - 4 } & Southern Bleached Hardwood Kraft & SBHK & 85 \\
\cline { 2 - 4 } & Northern Bleached Hardwood Kraft & NBHK & 89 \\
\hline \multirow{3}{*}{ Softwood } & Southern Bleached Softwood Kraft & SBSK & 86 \\
\cline { 2 - 4 } & Northern Bleached Softwood Kraft & NBSK & 87 \\
\hline \multirow{2}{*}{ Recycled } & Deinked Pulp & DIP & 74 \\
\hline \multirow{3}{*}{ Non-wood } & Semi-bleached Wheat Straw Soda & SBWS & 55 \\
\cline { 2 - 4 } & Bleached Wheat Straw Soda & BWS & 66 \\
\cline { 2 - 4 } & Bleached Bamboo Soda & Bamboo & 83 \\
\hline
\end{tabular}

\section{Production of Handsheets}

The procedure used to make the handsheets was a modified version of TAPPI T 205 sp-02 (2006). The procedure will be briefly described, and the differences from the TAPPI procedure will be highlighted. Twenty-four grams (oven-dried) of pulp were disintegrated using a standard pulp disintegrator (Pulp Disintegrator, Testing Machines Inc., New Castle, DE, USA) at a 1.2\% consistency using 15,000 revolutions. After disintegration, the pulp suspension was diluted to a $0.3 \%$ consistency. After dilution, 200 $\mathrm{mL}$ of the suspension were measured to make handsheets using a standard handsheet former (Sheet Former, Testing Machines Inc., New Castle, DE, USA). The target basis weight for the handsheets was $30 \mathrm{~g} / \mathrm{m}^{2}$. After forming and couching against the smooth surface of blotting paper, the wet handsheets were not pressed to avoid densification. Density is an important property for tissue products. Industrially, tissue products are manufactured using low levels of wet pressing to minimize densification and subsequent loss of softness and water absorbency (de Assis et al. 2018b). The handsheets were dried using a drum drier (Formax 12" Drum Dryer, Adirondack Machine Corp., Hudson Falls, $\mathrm{NY}$, USA) at $110{ }^{\circ} \mathrm{C}$ and $1 \mathrm{rpm}$ to solids contents above $95 \% \mathrm{w} / \mathrm{w}$. Before drying, an additional sheet of blotting paper was placed on the top of the couched handsheet (blotter, handsheet, blotter). Five passes on the drum drier were necessary to dry the handsheets. 
Before testing, the handsheets were peeled off from the blotting paper and conditioned at $50 \%$ relative humidity and an ambient temperature of $23{ }^{\circ} \mathrm{C}$ (TAPPI T402 sp-08 2013). Unrefined and refined pulps were studied.

\section{PFI Refining}

Mechanical refining is a well-known unit operation used by the pulp and paper industry to develop fiber properties for papermaking. The refining process applies compression and shearing forces to fiber in the wet state to modify the wet fiber flexibility and fiber bonding ability. The refining process causes fibrillation at the fiber surface, detachment of fiber fines, and delamination of the fiber cell wall, which increases the fiber wet-flexibility, cell wall porosity, and swelling. As a result of those morphological modifications, refined fibers present an improved bonding ability and conformability, which increases the paper strength and density (Hubbe et al. 2007). In this study, the pulps were refined using a PFI refiner (PFI Mill $-\mathrm{n}^{\circ} 312$, The Norwegian Pulp and Paper Research Institute, Oslo, Norway), according to TAPPI T 248 sp-00 (2000). The PFI refiner is a batch equipment, in which the fibers are refined between a roll with bars and smoothwalled housing, which are both rotating in the same direction, but at different speeds to create a differential rotational action. The refining action is achieved by the differential rotational action and by the application of loading that pushes the roll bars against the housing walls for a specified number of revolutions. Twenty-four grams (oven-dried) of properly disintegrated pulp were diluted to a $10 \%$ consistency before the refining process. Different levels of refining were appropriately selected for each pulp individually. Pulp freeness (Canadian standard freeness - CSF) was measured for all of the refining levels, according to TAPPI T 227 om-99 (1999). Because tissue paper requires lower levels of strength compared with printing and packaging paper, low levels of refining are usually applied to minimize the loss of water absorbency and softness associated with the development of dense and strong fiber webs (de Assis et al. 2018b). Table 2 presents all of the refining levels applied to each pulp and the corresponding CSF.

Table 2. Mechanical Refining Levels Applied to Hardwood, Softwood, Recycled, and Non-wood Pulps and the Corresponding CSF.

\begin{tabular}{|c|c|c|}
\hline Pulp Type & Pulp Name & $\begin{array}{l}\text { PFI Refining Revolution } \\
(\mathrm{mL} \text { of } \mathrm{CSF})^{*}\end{array}$ \\
\hline \multirow{4}{*}{ Hardwood } & Bleached Eucalyptus Kraft & Unrefined (630)*, 1000 (569), 2000 (522) \\
\hline & Bleached Acacia Kraft & Unrefined (605), 500 (541), 1000 (511), 2000 (448) \\
\hline & Southern Bleached Hardwood Kraft & Unrefined (672), 1000 (563), 2000 (470) \\
\hline & Northern Bleached Hardwood Kraft & Unrefined (578), 500 (516), 1000 (474) \\
\hline \multirow{2}{*}{ Softwood } & Southern Bleached Softwood Kraft & Unrefined (727), 1000 (708), 2000 (632), 3000 (538) \\
\hline & Northern Bleached Softwood Kraft & Unrefined (692), 1000 (676), 3000 (596), 5000 (522) \\
\hline Recycled & Deinked Pulp & Unrefined (393), 500 (299), 1000 (252) \\
\hline \multirow{3}{*}{ Non-wood } & Semi-bleached Wheat Straw Soda & Unrefined (423), 250 (364), 500 (266) \\
\hline & Bleached Wheat Straw Soda & Unrefined (351), 250 (241), 500 (228) \\
\hline & Bleached Bamboo Soda & Unrefined (698), 1000 (618), 2000 (537), 3000 (363) \\
\hline
\end{tabular}

${ }^{\star}$ Numbers not in parentheses represent the different PFI revolutions applied; numbers in parentheses represent the CSF $(\mathrm{mL})$ for a given refining level 
In this study, virgin wood pulps (BEK, acacia, SBHK, NBHK, SBSK, and NBSK) were refined until a freeness value of approximately $550 \mathrm{~mL}$ to $450 \mathrm{~mL}$ of CSF was reached. This value was chosen based on typical freeness values used in industrial tissue manufacturing (Watson and Janssen 2014). In contrast, wheat straw (SBWS and BWS) and recycled (DIP) pulps have starting freeness levels lower than $450 \mathrm{~mL}$ of CSF. In those cases, lighter refining was applied to slightly develop the strength and evaluate the effect of refining on the tissue paper properties.

\section{Handsheet Testing}

The procedures used to test the tissue paper properties and evaluate the fiber morphology will be briefly described here. The values herein presented for all of the measured properties and at all of the refining levels are the average of a minimum of six measurements, with exceptions given to the basis weight and bulk, where a minimum of 25 sheets were tested, fiber morphology and surface roughness (three measurements), and water absorbency capacity (two measurements).

The basis weight (mass per unit of surface area) and bulk (inverse of the apparent density) were measured according to TAPPI T 410 om-08 (2013) and TAPPI T 580 pm-12 (2012), respectively. The tensile strength (maximum tensile force per unit of width) was measured according to ISO 12625-4 (2005) using INSTRON tensile tester (INSTRON Model 4443, Canton, MA, USA). The tensile strength was divided by the basis weight and gravitational acceleration $\left(9.8 \mathrm{~m} / \mathrm{s}^{2}\right)$ to calculate the tensile breaking length. The water absorbency capacity per unit of mass was measured according to ISO 12625-8 (2010). Five grams of handsheets were used for each water absorbency test. The swellability of the handsheets after the water absorbency test was also measured. The swellability was calculated as the ratio between the wet caliper (after water absorbency) and dry caliper (before water absorbency). During this procedure, a small handsheet sample (40 $\mathrm{mm}$ x 40 $\mathrm{mm}$ ) was placed on a flat microscope slide of known thickness and the dry caliper was measured according to TAPPI T 580 pm-12 (2012). In a second instance, water was used to swell the handsheet sample. Following the water absorbency capacity procedure (ISO 12625-8, 2010), sufficient water was placed on the microscope slide to fully cover the handsheet sample during 30 seconds. After that time, the microscope slide was place at a angle of $30^{\circ}$ to drain the excess water during $1.0 \mathrm{~min}$. The wet caliper was measured after the draining period. The dry and wet calipers were determined by discounting the thickness of the microscope slide.

The softness of handsheets was assessed with a panel, following the procedure described by Ko and Park (2016b). The samples were given to 10 trained panelists who were asked to rank the samples from the least soft to the softest according to the rank order method. After ranking the samples, the panelists were asked to assign a score to each sample according to the rating method. The least soft and softest samples selected during the rank order method were assigned a score of 0 and 100, respectively. The panelists were free to assign any score ranging from 0 to 100 to the remaining samples. The panel was executed individually in a controlled environment $\left(50 \%\right.$ relative humidity, $23{ }^{\circ} \mathrm{C}$ ambient temperature) (TAPPI T402 sp-08 2013). Softness was also assessed using a Tissue Softness Analyzer (TSA, EMTEC Electronic GmbH, Leipzig, Germany) (Grüner 2016). During this measurement, a sound spectrum was generated as a result of the friction experienced by a group of six vertical lamellas that rotate horizontally on the surface of the tissue paper sample. In the generated sound spectrum, a peak in the sound intensity around $6500 \mathrm{~Hz}$ (TSA softness, also called the TS7 - dB) is the result of the lamellas vibrating. This peak 
is an indication of the "real" softness and is influenced by many variables (e.g., type of fibers, fiber bonding strength, free fiber ends, internal structure, machine technology, creping, and chemicals). A lower TS7 peak intensity value indicates higher softness. The previous work by Wang et al. (2019) showed a good correlation between the softness panel test and TS7 measurement for bath tissue in the USA market. Another peak observed in the sound spectrum around $750 \mathrm{~Hz}$ (TSA smoothness, also called TS750 - dB) is the result of the sample vibrating and is mainly related to the surface structure and geometry, and it is influenced by surface finishing (e.g. creping, embossing, calendering). This peak is an indication of surface smoothness or roughness, defined as the degree to which a surface contains short-span or fine irregularities. A lower TS750 peak indicates higher surface smoothness. Also, the TSA in-plane stiffness (TSA stiffness, also called D - mm/N) was measured. During the measurement, the vertical lamelas applied a vertical force from 0.1 $\mathrm{N}$ to $0.6 \mathrm{~N}$ on the sample, stretched as a membrane, while the vertical displacement was measured. The TSA stiffness was calculated as the ratio between the displacement and applied vertical force. TSA stiffness can be used as an indication for bulk softness. A higher value for D indicates better bulk softness. TSA stiffness is influenced by type of fiber, refining, chemicals, and machine technology. Because differences may exist between the two sides of a handsheet (wire and blotting paper), the softness measurements were performed on both sides of each sample, and the values presented are the arithmetic mean of both sides. Surface roughness was also measured using a Kawabata Evaluation System (KES) using KES-FB4 surface tester (KatoTech, Kyoto, Japan). The contactor, which was used to measure surface roughness was made by a steel piano wire with diameter of 0.5 $\mathrm{mm}$. The wire was bent in a "U" shape to give a total length of $5 \mathrm{~mm}$. During the measurement, the sample was placed horizontally on a smooth steel plate, and a contact force of $10 \pm 0.5 \mathrm{~g}$ was applied between the contactor and the sample. The sample was moved in $2 \mathrm{~cm}$ interval with a constant velocity of $0.1 \mathrm{~cm} / \mathrm{s}$ while the contactor was kept its position. After the measurement, the surface roughness (SMD) was calculated as the mean deviation of the thickness according to Eq. 1,

$$
S M D=\frac{1}{X} \int_{0}^{x}|T-\bar{T}| d x
$$

where SMD is the mean deviation of thickness $(\mu \mathrm{m}), X$ has the value of $2 \mathrm{~cm}$ taken as the standard length for measurement, $x=$ displacement of the contactor on the surface of the sample, $T$ is the thickness of the sample measured by the contactor at position $\mathrm{x}$, and $\bar{T}$ is the mean value of thickness. A higher SMD value indicates higher surface roughness.

\section{Fiber Morphology}

A HiRes Fiber Quality Analyzer (FQA) (OpTest Equipment Inc., Hawkesbury, Canada) was used to measure the fiber length, fiber width, coarseness, fiber population and fines content. Properly disintegrated samples were diluted to approximately $1 \mathrm{mg} / \mathrm{L}$ to 5 $\mathrm{mg} / \mathrm{L}$. The fiber length was measured for fibers longer than $0.2 \mathrm{~mm}$, and at least 10000 fibers were analyzed for each FQA run. The fiber length distribution was obtained, and the length-weighted average fiber length $\left(L_{\mathrm{w}}\right)$ was calculated according to Eq. 2,

$$
L_{\mathrm{w}}=\frac{\sum n_{\mathrm{i}} L_{\mathrm{i}}^{2}}{\sum n_{\mathrm{i}} L_{\mathrm{i}}}
$$

where $n$ is the fiber count and $L$ is the fiber length (mm).

The fiber width was measured for fibers longer than $0.2 \mathrm{~mm}$ for width values ranging from $7 \mu \mathrm{m}$ to $60 \mu \mathrm{m}$. The arithmetic mean of the fiber width was calculated. The 
fines content was measured for particles larger than $0.025 \mathrm{~mm}$ and smaller than $0.2 \mathrm{~mm}$, and the length-weighted percentage of fines $\left(F_{\mathrm{w}}\right)$ was calculated according to Eq. 3 ,

$$
F_{\mathrm{w}}(\%)=100 \times \frac{\sum n_{\mathrm{i}} L_{\mathrm{i}}}{L_{\mathrm{T}}}
$$

where $n$ is the number of fines, $L_{\mathrm{i}}$ is the fines length $(\mathrm{mm})$, and $L_{\mathrm{T}}$ is the total fiber length (mm).

Handsheets were used to measure the fiber coarseness and fiber population. Approximately $30 \mathrm{mg}$ to $40 \mathrm{mg}$ of the handsheets on a dry basis were disintegrated and diluted in $5 \mathrm{~L}$ of water. Two hundred milliliters of the dilute fiber suspension were collected, diluted to approximately $2 \mathrm{mg} / \mathrm{L}$, and used for the coarseness measurement. During the coarseness measurements, all of the fibers in the dilute suspension were measured. The coarseness $(\mathrm{mg} / \mathrm{km})$ was calculated by dividing the total mass of the fibers by the total length of the fibers measured. Fiber population (million fibers/g) was calculated by dividing the total number of fibers by the total mass of fibers.

\section{Surface Chemistry}

To better evaluate the effect of the fiber features on the tissue properties, the surface chemistry of the handsheets was measured using X-ray photoelectron spectroscopy (XPS). Handsheets of the hardwood fiber were made using TAPPI T 205 sp-02 (2006). After forming and couching, the handsheets were pressed against a metal plate covered with aluminum foil to avoid any surface contamination that could introduce error in the analysis. The handsheets were dried overnight in a conditioned room at a 50\% relative humidity and ambient temperature of $23{ }^{\circ} \mathrm{C}$ (TAPPI T402 sp-08 (2013)). The smooth surface of the handsheets (surface in contact with the aluminum foil) was used for the XPS analysis. The XPS spectra were obtained with a SPECS FlexMod system (SPECS, Berlin, Germany) equipped with an $\mathrm{Al} / \mathrm{Mg} \mathrm{X}$-ray source and PHOIBOS 150 analyzer (SPECS, Berlin, Germany). The takeoff angle was normal to the surface. The X-ray incidence angle was approximately $30^{\circ}$ from the sample surface, and the angle between the X-ray source to the analyzer was approximately $60^{\circ}$. Energy calibration was established by referencing to adventitious carbon ( $\mathrm{C} 1 \mathrm{~s}$ line at $285.0 \mathrm{eV}$ binding energy). Base pressure in the analysis chamber was in $10^{-10}$ mbar range. A Gaussian curve fitting was executed to treat the $\mathrm{C} 1 \mathrm{~s}$ signal and estimate the relative area of the $\mathrm{C} 1(\mathrm{C}-\mathrm{H}, \mathrm{C}-\mathrm{C}), \mathrm{C} 2(\mathrm{C}-\mathrm{O}), \mathrm{C} 3(\mathrm{C}=\mathrm{O}$ or $\mathrm{O}-\mathrm{C}-$ $\mathrm{O})$, and $\mathrm{C} 4(\mathrm{O}=\mathrm{C}-\mathrm{O})$ groups. The following binding energies relative to the $\mathrm{C}-\mathrm{C}$ position were applied for each assigned group: $1.4 \mathrm{eV}$ for $\mathrm{C}-\mathrm{O} ; 2.9 \mathrm{eV}$ for $\mathrm{C}=\mathrm{O}$ or $\mathrm{O}-\mathrm{C}-\mathrm{O}$; and 4.2 $\mathrm{eV}$ for $\mathrm{O}=\mathrm{C}-\mathrm{O}$.

\section{RESULTS AND DISCUSSION}

\section{Fiber Morphology}

Fiber morphology has an important influence on the properties of tissue paper products. Softwood fibers are primarily used to impart strength. Softwood fibers are long and can form inter-fiber bonding with multiple fibers (Trepanier 2017). Softwood fibers with thin and low coarseness cell walls can be easily flattened into ribbon-like fibers, especially after refining, to reinforce the fiber web. Softwood fibers with thick cell walls are less likely to collapse and result in a bulkier and more absorbent tissue paper (Nanko et al. 2005). Additionally, thin softwood fibers are flexible and can provide good softness 
(Zou 2017a). Hardwood fibers are primarily used to impart softness and bulk. Short and slender hardwood fibers with relatively thick cell walls (relative high coarseness) can be used to impart bulk and water absorbency, especially at low refining levels (Hall 1983; Nanko et al. 2005). Hardwood fibers with thin cell walls are more flexible and can be used to provide good softness (Axelsson 2001). When compared with virgin fibers, recycled fibers have a low wet-flexibility, which reduces the inter-fiber bonding ability and yields a weaker tissue paper product (McKinney 1995; Hubbe et al. 2007). Recycled pulp typically contains a high content of short fibers and fines, which negatively affects the pulp drainage. The fines fraction is typically composed of cellulosic particles (e.g., fiber fragments, vessels, and ray cells) and contaminants (e.g., fillers, ink, and stickies) that may be detrimental to the paper making process and paper properties (Hubbe et al. 2007). Recycled fibers are stiff and do not have the flexibility necessary to provide a good softness or strength. However, stiff fibers are more dimensionally stable and can be used to impart bulk and water absorbency (McKinney 1995; Hubbe et al. 2007). Mechanical pulps are less flexible and less conformable than chemical pulps because of the higher lignin content and lower porosity, which yields tissue products with an improved bulk and low strength (Johnsson 1978; Hubbe et al. 2007). Figures 1 and 2 present morphology data for all of the market pulps studied.

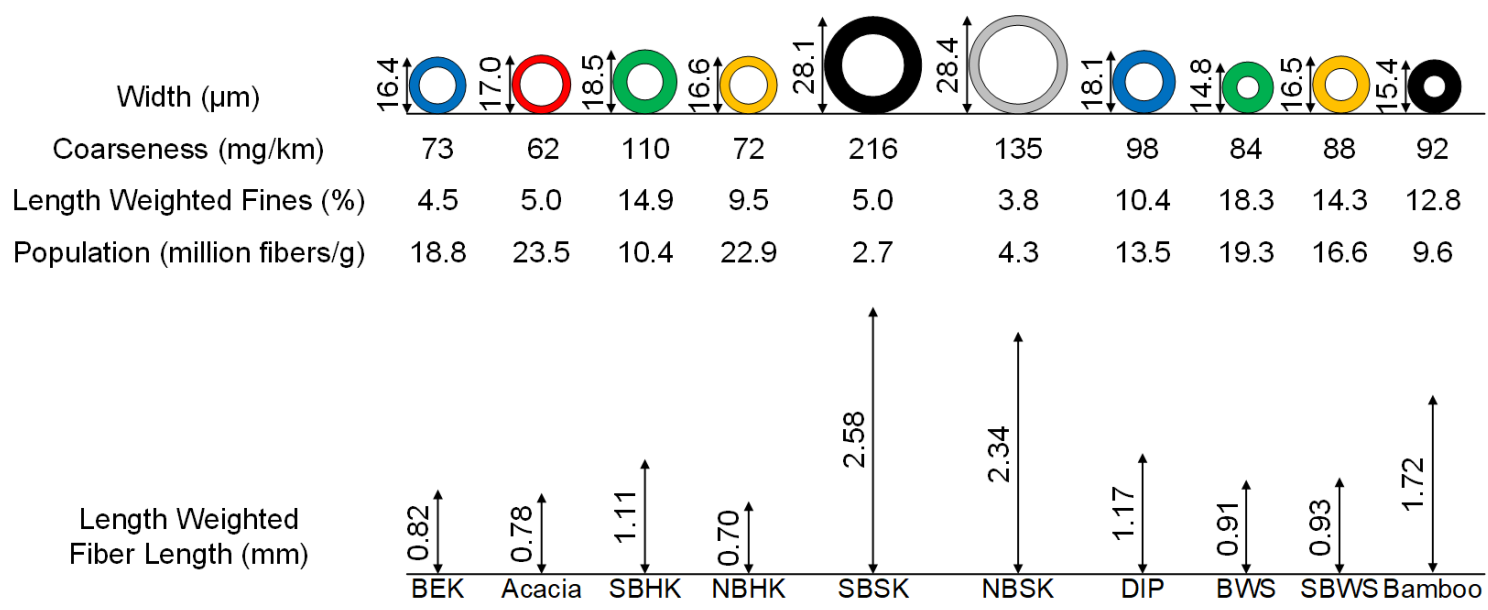

Fig. 1. Average fiber width, cell wall coarseness, length-weighted percentage of fines, fiber population and length weighted average fiber length for the hardwood, softwood, recycled, and non-wood pulps.

Among the hardwood pulps, the BEK and acacia pulps had similar fiber lengths $(\sim 0.8 \mathrm{~mm})$ and fines contents $(\sim 5 \%)$. However, the BEK pulp had a lower fiber width and higher coarseness than that of the acacia pulp. The BEK and NBHK pulps had similar fiber widths $(\sim 16.5 \mu \mathrm{m})$ and coarseness values $(\sim 73 \mathrm{mg} / \mathrm{km})$. However, the BEK pulp had longer fibers and a lower fines content than that of the NBHK pulp. The SBHK pulp had a different morphology among all of the hardwood pulps. The SBHK pulp had longer, wider, and coarser fibers than the other three hardwood pulps. As a result, SBHK fiber population was much lower than the fiber population of other hardwood pulps. The BEK, acacia, and NBHK pulps had a narrower fiber length distribution than the SBHK pulp. The low fines content and narrow fiber length distribution observed for the BEK and acacia pulps were the result of the use of a single or few wood species from well monitored plantations for pulp manufacturing (Hall 1983; Nanko et al. 2005; Pavan 2011). The NBHK pulp also had 
a narrow fiber length distribution, and it was likely to be manufactured from a single or few species coming from natural forests. In contrast, the use of trees with different ages and multiple species gave the SBHK pulp a broad fiber length distribution. A narrower distribution for the fiber morphology was observed in the market pulps produced from a single species and contributed to the increased product uniformity and process runnability consistency (Nanko et al. 2005).
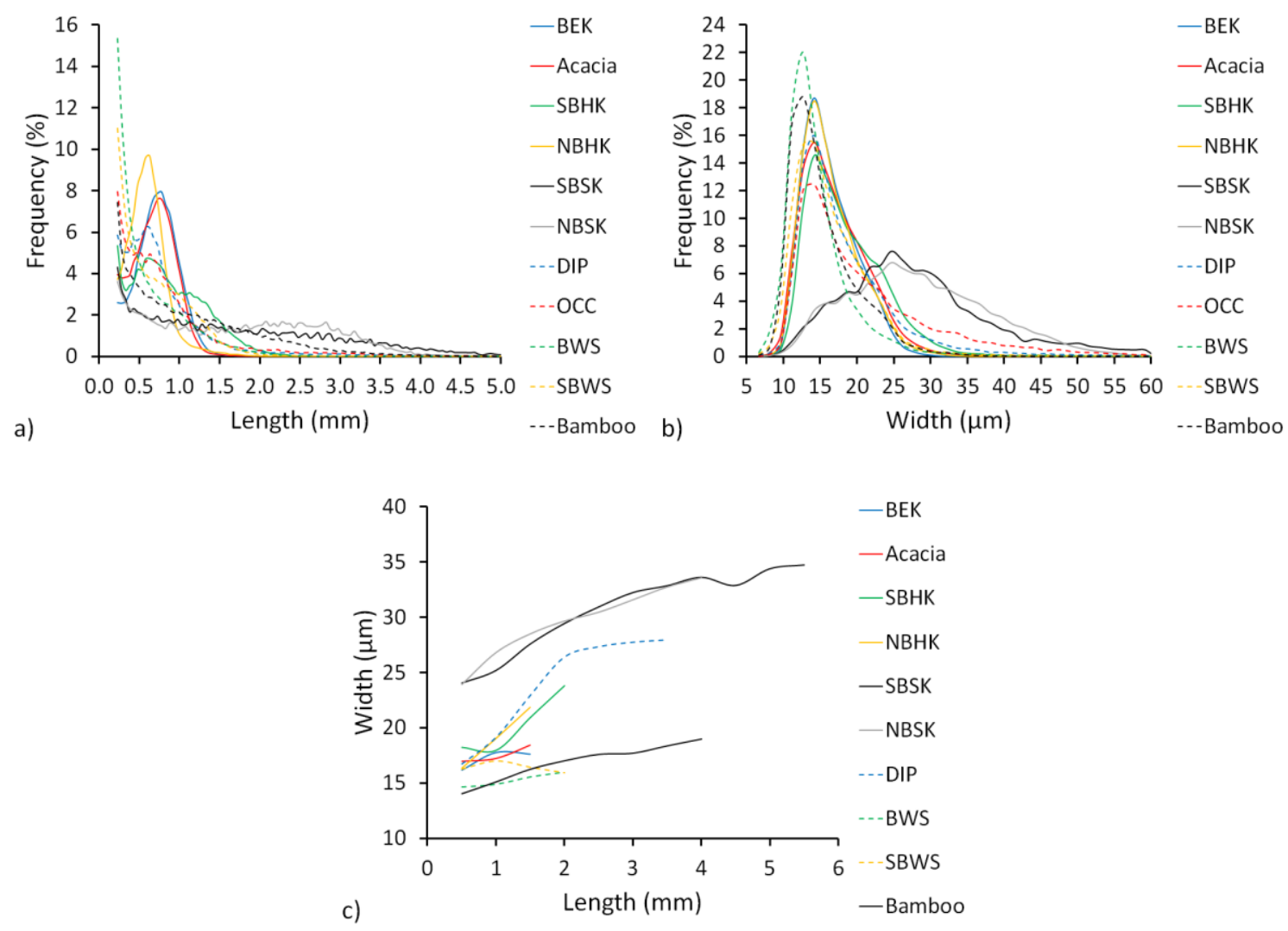

Fig. 2. Fiber length and fiber width distribution for the hardwood, softwood, recycled, and nonwood pulps: (a) fiber length distribution, (b) fiber width distribution, (c) fiber length vs fiber width.

The major difference among the softwood pulps was the fiber coarseness and fiber population. The fiber coarseness for the SBSK pulp $(\sim 215 \mathrm{mg} / \mathrm{km})$ was $60 \%$ higher than the fiber coarseness for the NBSK pulp $(\sim 135 \mathrm{mg} / \mathrm{km})$. Due to its higher coarseness, SBSK pulp presented a much lower fiber population ( 2.7 million fibers $/ g)$ than NBSK pulp (4.3 million fibers $/ g)$. The SBSK pulp had a slightly longer fiber length $(\sim 2.6 \mathrm{~mm})$ and higher fines content $(\sim 5 \%)$ than the NBSK pulps $(\sim 2.3 \mathrm{~mm}$ in length and $\sim 4 \%$ content of fines). Both the SBSK and NBSK pulps had a broad fiber length and fiber width distributions because they are typically produced from trees with different ages and from different species (Nanko et al. 2005).

As was expected, the recycled pulp (DIP) had a higher fines content $(\sim 10 \%)$ and higher content of short fibers (length $<0.5 \mathrm{~mm}$ ) compared with those of the virgin wood fibers (Hubbe et al. 2007). The DIP pulp had a fiber length distribution, fiber width, and fiber population that fell between those of the hardwood and softwood pulps because it is typically composed of a blend of short and long fibers. 
Both the wheat straw (BWS and SBWS) and bamboo pulps had similar fiber width $(\sim 15 \mu \mathrm{m}$ to $16 \mu \mathrm{m})$ and fiber coarseness $(\sim 85 \mathrm{mg} / \mathrm{km}$ to $90 \mathrm{mg} / \mathrm{km})$. However, the bamboo pulp had longer fibers $(\sim 1.7 \mathrm{~mm})$ and a lower fines content $(\sim 13 \%)$ compared with those of the wheat straw pulps ( $\sim 0.9 \mathrm{~mm}$ length and $14 \%$ to $18 \%$ fines content). The fraction of fines present in the wheat straw and bamboo pulps was mainly represented by non-fibrous cells (e.g., parenchyma cells and vessels) (Singh et al. 2011; Cao et al. 2014). Due to its short length, the fiber population of wheat straw ( $\sim 17$ to 19 million fibers/g) was much higher than the fiber population of bamboo pulp ( 10 million fibers/g). The wheat straw and bamboo pulps had a broad fiber length distribution with a high fines content and short fibers (length $<0.5 \mathrm{~mm}$ ). The wheat straw pulps had a higher amount of short fibers than the bamboo pulp, whereas the bamboo pulp had a higher content of long fibers (length > $2.0 \mathrm{~mm}$ ) compared with that of the wheat straw pulps.

The comparison among all of the pulps in terms of the fiber morphology showed that the bamboo pulp had a fiber morphology that was in between that of the hardwood and softwood pulps. The bamboo pulp had fibers that were longer than the hardwood pulps, but shorter than the softwood pulps. The fiber length distribution of the bamboo pulp was broader than the hardwood pulps, but less broad than the softwood pulps. The fiber width and coarseness for the bamboo pulp were similar to those of the hardwood pulps. However, bamboo had a higher fines content than the wood pulps. The fiber length distribution for the wheat straw pulps was similar to the recycled pulp, but with a higher fines content and short fibers (length $<0.5 \mathrm{~mm}$ ). The fiber length, fiber width, and coarseness for the wheat straw pulps were similar to those of the hardwood pulps. The wheat straw pulps had a higher fines content than the wood pulps.

\section{Bulk (Inverse of the Apparent Density)}

The bulk can be considered the major difference between tissue paper and other paper grades (e.g., writing, printing, and packaging) (de Assis et al. 2018b). Usually, the bulk correlates well with the water absorbency and softness (the higher the bulk, the higher the water absorbency and softness) (Novotny 1988). The fiber type plays an important role in the tissue paper bulk. Cellulosic fibers with a high Runkel ratio $(2 \times$ cell wall thickness / lumen diameter) are more rigid and resistant to collapse and yield bulkier tissue paper products. High yield fibers can also be used to provide a high bulk. High yield pulps are less flexible and less collapsible than low yield pulps because of the higher lignin content and lower cell wall porosity (Nanko et al. 2005). Recycled fibers can also be used to impart bulk. Recycled fibers are stiff and have a low wet flexibility, which yields tissue paper with a reasonable bulk (Hubbe 2006).

Figure 3 presents the pulp freeness and handsheet bulk (inverse of the apparent density) at different refining levels. SBHK and NBHK pulps presented faster drops in freeness with the increase of refining energy (PFI revolutions) than BEK and acacia pulps. Differences in fiber population and fines content can possibly be used to explain this behavior. SBHK pulp had a much lower fiber population than BEK, acacia, and NBHK pulps. The applied refining energy was based on the total mass of fibers used during the refining process ( $24 \mathrm{~g}$ oven-dried) and did not consider the number of fibers present in that mass. Therefore, the refining energy per fiber was higher for SBHK pulp due to its lower fiber population, which resulted in a more effective refining and faster reduction of freeness. In addition, SBHK and NBHK pulps had a higher content of fines than BEK and acacia pulps. The refining process has the potential to disaggregate and disintegrate the existing fines, which further contribute for a faster decrease of drainage. Among all 
softwoods, SBSK pulp also presented a faster drop in freeness than NBSK pulp. As discussed before, the refining energy per fiber was higher for the SBSK pulp due to its lower fiber population, which contributed for the faster decrease in freeness with the increase of refining energy (Palmer et al. 2009). The non-wood and recycled pulps also presented a faster decrease in freeness than the wood pulps as the refining energy was increased. Refining increased the wet flexibility and caused breakage of the stiff recycled fibers increasing the content of short fibers and fines, which contributed for a fast reduction of drainage (Hubbe et al. 2007). Refining of non-wood pulps is known to cause disaggregation and disintegration of non-fibrous cells (e.g., parenchyma cells), which further decreases the drainage and increases the fiber web density (Subrahmanyam et al. 2000).

Among all of the hardwood pulps, the SBHK pulp presented a higher bulk, especially in the unrefined state. SBHK pulp had lower amount of short fibers (length < $0.5 \mathrm{~mm}$ ), higher amount of long fibers (length $>1.25 \mathrm{~mm}$ ), and coarser fibers than any other hardwood pulp. The combination of long and coarse fibers that were less flexible and more resistant to collapse contributed for the creation of larger inter-fiber pores, which resulted in superior bulk, especially at the unrefined state where the wet fiber flexibility was not fully developed. During the refining process, compression and shearing forces experienced by fibers increased the cell wall collapsibility and wet fiber flexibility, which resulted in a significant reduction in bulk. The BEK and acacia pulps presented similar bulk values at a given freeness. As was discussed before, the BEK and acacia pulps had similar fiber morphologies. In contrast, the NBHK pulp presented the lowest bulk among all of the hardwood pulps. The NBHK pulp had shorter fibers and a higher fines content, which contributed to an increased sheet density. Between the softwood pulps, the SBSK pulp presented a higher bulk than the NBSK pulp for all of the freeness values. The SBSK fibers were coarser, less flexible and more resistant to collapse than the NBSK fibers. The NBSK fibers had a high width and thin cell walls, which made them flexible and more readily flattened into ribbon-like fibers, especially after refining. The bamboo pulp had a behavior that was in between that of the hardwood and softwood pulps. At lower refining levels, the bamboo pulp had a bulk comparable to that of the SBHK and SBSK pulps. At higher refining levels, the bamboo pulp had a similar bulk to that of the BEK, acacia, SBHK, and SBSK pulps.
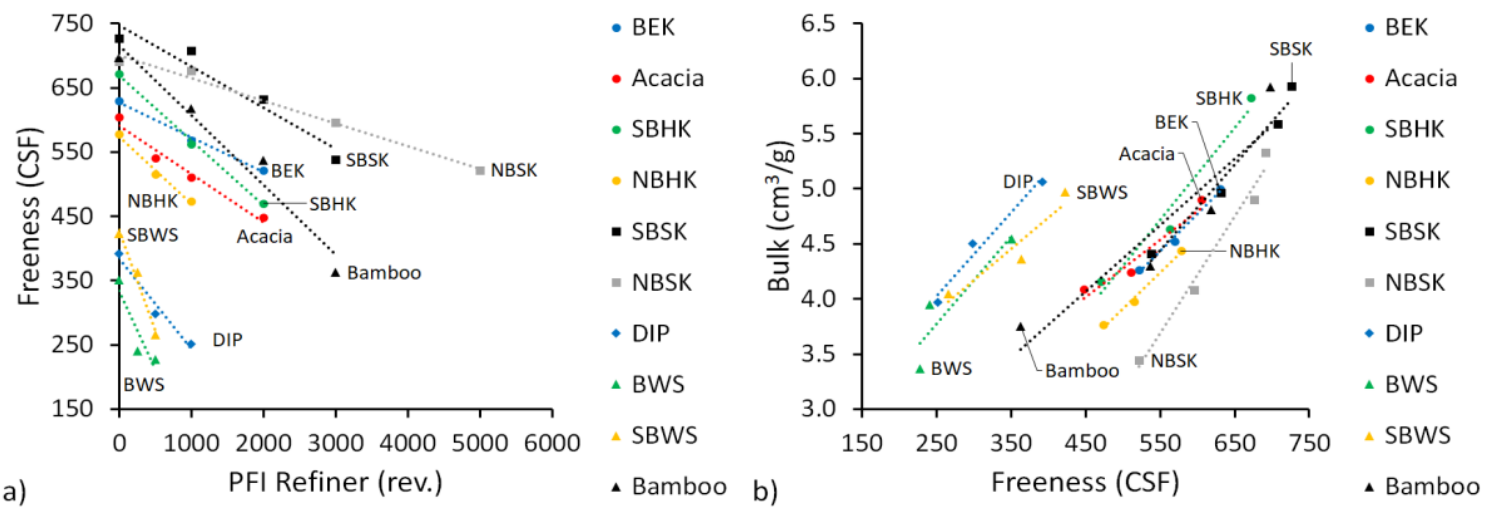

Fig. 3. Pulp freeness and handsheet bulk (inverse of the apparent density) for the hardwood, softwood, recycled, and non-wood pulps at different refining levels: (a) CSF ( $\mathrm{mL})$ as a function of the PFI refiner revolutions and (b) handsheet bulk as a function of the CSF $(\mathrm{mL})$. 
The recycled pulp had lower freeness than the hardwood, softwood, and bamboo pulps because of the high content of short fibers and fines. Additionally, the recycled pulp was refined previously, which further decreased its drainability. Therefore, it was expected that a refined pulp with a high content of short fibers and fines would have a lower freeness and yield denser fiber webs. However, the recycled pulp presented a relatively good bulk. The DIP pulp had a similar bulk to that of the BEK and acacia pulps, but a lower freeness. The explanation for this behavior was related to the lack of flexibility of the recycled fibers. The recycling process promotes fiber hornification (loss of ability to swell in water) and increases the stiffness of recycled fibers, which contributes to the formation of a bulkier fiber web (McKinney 1995; Hubbe et al. 2007). The wheat straw pulps had a behavior distinct from that of the other virgin pulps and a similar behavior to the DIP pulp. The wheat straw pulps had a lower unrefined freeness because of the high content of short fibers and fines (parenchyma cells and vessels), which yielded a denser fiber web. The SBWS had a higher bulk than the BWS pulp, probably because of its lower fines content and higher semi-bleached fiber rigidity.

Among all of the virgin fibers, the SBSK, bamboo, SBHK, and NBSK pulps had a higher unrefined bulk than all of the other pulps. Long fibers with a high coarseness were less prone to collapse and formed a less dense paper web in an unrefined state.

\section{Water Absorbency Capacity}

Water absorbency is an important property for tissue paper products used for drying and wiping purposes, such as hand and kitchen towels. Water absorbency is a complex and dynamic phenomenon that is influenced by many physical, chemical, and morphological aspects of cellulosic fibers (e.g., surface composition, surface roughness, bulk composition, charged groups, cell wall porosity, and fiber web porosity) (Hubbe et al. 2015). The combination of hydrophilic fibers in a porous, bulky and stable fiber web structure results in tissue paper products with a high water absorbency (Beuther et al. 2010). In a saturated tissue paper, the water is located in the spaces between plies and fibers, in the fiber lumen, and inside the porous structure of the fiber cell wall (Kullander 2012). However, most of the water is located in the spaces between fibers. Therefore, it was expected that tissue paper sheets with a higher bulk (a high volume of pores between the fibers) would present a higher water absorbency capacity. It was expected that there would be a correlation between the bulk and water absorbency capacity.

Figure 4a presents a good linear correlation (coefficient of determination, $\mathrm{R}^{2}=$ 0.77 ) between the water absorbency capacity and bulk for all of the market pulps at different refining levels. Figure $4 \mathrm{~b}$ presents the same data shown in Fig. $4 \mathrm{a}$ and highlights each market pulp at different refining levels. When the market pulps were evaluated individually, it was realized that the water absorbency decreased with an increase in the refining level and subsequent densification of the fiber web. A remarkable decrease in the water absorbency was observed, even at low refining levels. However, the bulk cannot be used to completely explain all of the differences in the water absorbency when the market pulps were compared with each other. As discussed previously, the water absorbency is a complex phenomenon influenced by many variables (e.g., fiber surface wettability, fiber swellability, sheet porous morphology, and sheet porous permeability) (Hubbe et al. 2015; Ko et al. 2016a). To be able to further discuss the effect of other fiber features on water absorbency, additional experiments were performed for the hardwood pulps. 

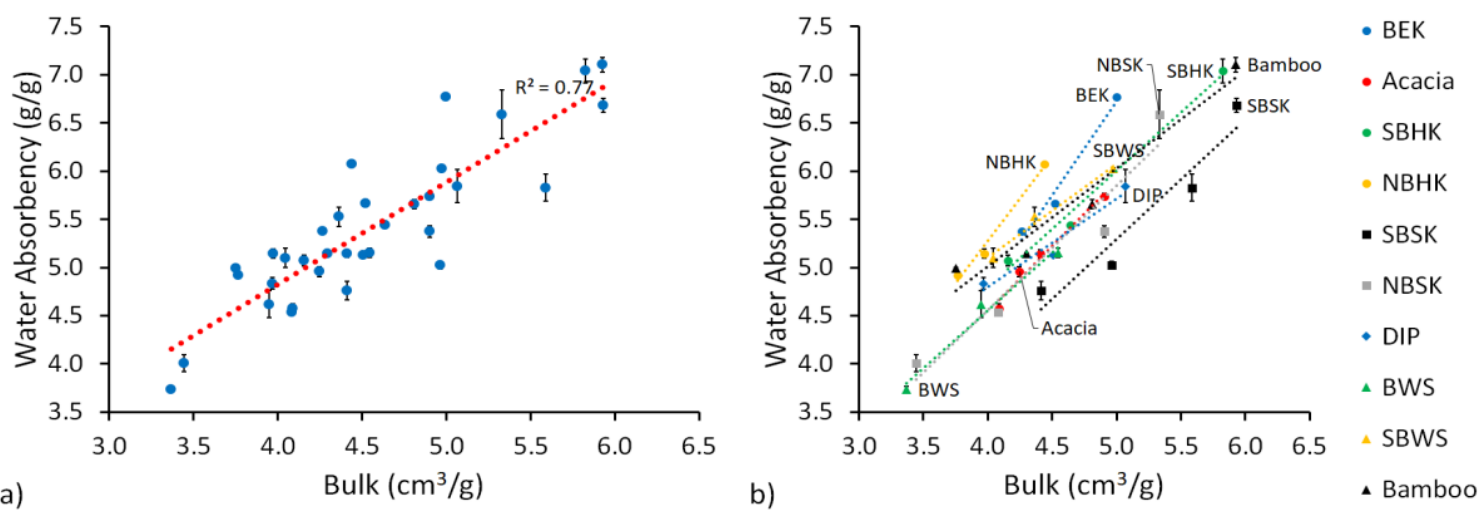

Fig. 4. Water absorbency capacity as a function of bulk (inverse of the apparent density) for the hardwood, softwood, recycled, and non-wood pulps at different refining levels: (a) correlation between the water absorbency capacity and bulk and (b) water absorbency capacity as a function of the bulk.

The total absorbed water after a water absorbency test $\left(A B S_{\text {total }}\left(\mathrm{g}_{\text {water }} / \mathrm{g}_{\text {fiber }}\right)\right)$ can be divided into water located in the spaces between plies $\left(A B S_{\text {plies }}\left(g_{\text {water }} / g_{\text {fiber }}\right)\right)$, in the pores between fibers $\left(A B S_{\text {pores }}\left(\mathrm{g}_{\text {water }} / \mathrm{g}_{\text {fiber }}\right)\right)$, and inside the cell wall as a result of fiber swelling $\left(A B S_{\text {swelling }}\left(\mathrm{g}_{\text {water }} / \mathrm{g}_{\text {fiber }}\right)\right)$. Equation 4 can be used as an approximation to calculate the total water absorbency:

$$
A B S_{\text {total }}\left(\frac{g_{\text {water }}}{g_{\text {fiber }}}\right)=A B S_{\text {pores }}+A B S_{\text {swelling }}+A B S_{\text {plies }}
$$

The volume of pores between fibers $\left(V_{\text {pores }}\left(\mathrm{m}^{3}\right)\right)$ of a sheet can be approximately estimated by subtracting the volume of fibers $\left(V_{\text {fiber }}\left(\mathrm{m}^{3}\right)\right)$ from the volume of a sheet in the dry state $\left(V_{\text {sheet dry }}\left(\mathrm{m}^{3}\right)\right)$ according to Eq. 5:

$$
V_{\text {pores }}=V_{\text {sheet dry }}-V_{\text {fiber }}
$$

Each element of Eq. 5 can be further developed using Eq. 6, where $m_{\text {water }}(\mathrm{kg})$ is the mass of water located in the pores between fibers, $\rho_{\text {water }}\left(\mathrm{kg} / \mathrm{m}^{3}\right)$ is the density of water $\left(1000 \mathrm{~kg} / \mathrm{m}^{3}\right), m_{\text {sheet }}(\mathrm{kg})$ is the mass of the sheet (mass of fibers), $\rho_{\text {sheet dry }}\left(\mathrm{kg} / \mathrm{m}^{3}\right)$ is the apparent density of the sheet in the dry state calculated by diving the sheet basis weight by the dry caliper, $\rho_{\text {fiber }}\left(\mathrm{kg} / \mathrm{m}^{3}\right)$ denotes the density of cellulosic fibers assumed to be similar to the density of cellulose $\left(1500 \mathrm{~kg} / \mathrm{m}^{3}\right)$.

$$
V_{\text {pores }}=\frac{m_{\text {water }}}{\rho_{\text {water }}} ; V_{\text {sheet dry }}=\frac{m_{\text {sheet }}}{\rho_{\text {sheet dry }}} ; V_{\text {fiber }}=\frac{m_{\text {sheet }}}{\rho_{\text {fiber }}}
$$

By combining Eqs. 5 and 6, $A B S_{\text {pores }}$ can be calculated according to Eq. 7.

$$
A B S_{\text {pores }}\left(\frac{g_{\text {water }}}{g_{\text {fiber }}}\right)=\frac{m_{\text {water }}}{m_{\text {sheet }}}=\frac{\rho_{\text {water }}}{\rho_{\text {sheet dry }}}-\frac{\rho_{\text {water }}}{\rho_{\text {fiber }}}
$$

The swellability of sheets can be calculated as the ratio between wet caliper (after water absorbency test) and the dry caliper (before water absorbency test), assuming that the expansions on the $\mathrm{X}$ and $\mathrm{Y}$ directions are negligible. 
Cellulosic fibers have a tendency to swell when in contact with water. The amorphous regions of cellulose, hemicellulose content, the presence of charged groups (e.g., carboxyl groups), and the cell wall porosity are some of the variables responsible for the swelling behavior of cellulosic fibers. Lignin and extractives are less hydrophilic than cellulose and hemicellulose, and they can negatively affect the wettability of cellulosic fibers (Hubbe et al. 2007; Hubbe et al. 2015). The higher the swelling or expansion in the thickness $(Z)$ direction experienced by a sheet during a water absorbency test, the higher will be the final water absorbency capacity. The increase in volume of the sheets due to sheet swelling $\left(V_{\text {swelling }}\left(\mathrm{m}^{3}\right)\right)$ can be calculated by the difference between the volume of the sheet after water absorbency test $\left(V_{\text {sheet wet }}\left(\mathrm{m}^{3}\right)\right)$ and before the water absorbency test $\left(V_{\text {sheet dry }}\left(\mathrm{m}^{3}\right)\right)$, according to Eq. 8 .

$$
V_{\text {swelling }}=V_{\text {sheet wet }}-V_{\text {sheet dry }}
$$

Equation 8 can be further developed using Eq. 9, where $m_{\text {water }}(\mathrm{g})$ is the mass of absorbed water due to sheet swelling, $\rho_{\text {water }}\left(\mathrm{kg} / \mathrm{m}^{3}\right)$ is the density of water $\left(1000 \mathrm{~kg} / \mathrm{m}^{3}\right)$, $\rho_{\text {sheet wet }}\left(\mathrm{kg} / \mathrm{m}^{3}\right)$ is the apparent density of the sheet in the wet state calculated by diving the sheet basis weight by the wet caliper, $\rho_{\text {sheet dry }}\left(\mathrm{kg} / \mathrm{m}^{3}\right)$ is the apparent density of the sheet in the dry state calculated by diving the sheet basis weight by the dry caliper, and $m_{\text {sheet }}(\mathrm{g})$ is the mass of the sheet (mass of fibers).

$$
V_{\text {swelling }}=\frac{m_{\text {water }}}{\rho_{\text {water }}} ; V_{\text {sheet wet }}=\frac{m_{\text {sheet }}}{\rho_{\text {sheet wet }}} ; V_{\text {sheet dry }}=\frac{m_{\text {sheet }}}{\rho_{\text {sheet dry }}}
$$

By combining Eqs. 8 and 9, $A B S_{\text {swelling }}$ can be calculated according to Eq. 10.

$$
A B S_{\text {swelling }}\left(\frac{g_{\text {water }}}{g_{\text {fiber }}}\right)=\frac{m_{\text {water }}}{m_{\text {sheet }}}=\frac{\rho_{\text {water }}}{\rho_{\text {sheet wet }}}-\frac{\rho_{\text {water }}}{\rho_{\text {sheet dry }}}
$$

Table 3 presents the caliper (dry and wet), sheet swelling, and water absorbency values for all hardwood pulps at various refining levels. As discussed before, the mechanical refining promoted the densification of the sheets, which caused the reduction of the volume of pores $\left(A B S_{\text {pores }}\right)$. However, the mechanical refining did not change the swellability of a given hardwood pulp $\left(A B S_{\text {swelling }}\right)$ significantly. By difference, it was

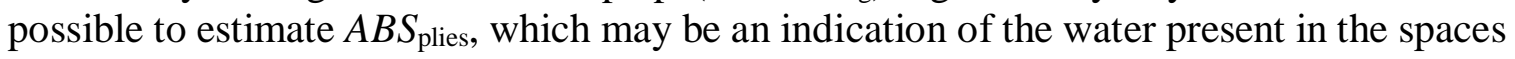
between plies (each absorbency test was performed with a stack of 14 to 15 handsheets 3 inches wide).

However, the separation of absorbed water in different fractions (plies, pores, and cell wall) has to be interpreted with caution. The caliper was measured at a specific pressure $(2 \mathrm{kPa})$ that may decrease the "real" thickness of the sheets in both dry and wet states, which would change the calculation for the distribution of water. In addition, $A B S_{\text {swelling }}$ is an indication of the swelling of the sheet, and it is not an indication of the swelling of fibers by themselves. The swelling of the fibers can have the effect of constricting the pores inside the sheet (Hubbe et al. 2015). Additionally, it was assumed that all the pore volume inside the sheet was completely filled with water $\left(A B S_{\text {pores }}\right)$ after the water absorbency test. In other words, the calculations presented here are just an approximation for the real situation.

When the hardwood pulps were compared to each other, differences in water absorbencies were found. The SBHK pulp presented the highest values for $A B S_{\text {pores }}$ at a 
given refining level, which is associated with its higher bulk (longer and coarser fibers). The BEK and acacia pulps presented similar $A B S_{\text {pores }}$ at a given refining level, as they displayed similar fiber morphology and bulk. The NBHK presented the lowest bulk (relatively shorter fibers with high content of fines) among all hardwoods and therefore, the lowest values for $A B S_{\text {pores. }}$ With exception of acacia pulp, all hardwoods presented similar sheet swelling $(\sim 20 \%$ to $25 \%)$ at different refining levels. Acacia presented the lowest sheet swelling $(\sim 15 \%)$. The $A B S_{\text {swelling }}$ for all hardwoods is around $1.0 \mathrm{~g}_{\text {water }} / \mathrm{g}_{\text {fiber, }}$, with exception of acacia $\left(\sim 0.65 \mathrm{~g}_{\text {water }} / \mathrm{g}_{\text {fiber }}\right)$.

Table 3. Water Absorbency of Hardwood Handsheets.

\begin{tabular}{|c|c|c|c|c|c|c|c|c|}
\hline $\begin{array}{l}\text { Market } \\
\text { Pulp }\end{array}$ & $\begin{array}{l}\text { PFI Refining } \\
\text { Revolutions }\end{array}$ & $\begin{array}{c}\text { Dry } \\
\text { Caliper } \\
(\mu \mathrm{m})\end{array}$ & $\begin{array}{c}\text { Wet } \\
\text { Caliper } \\
(\mu \mathrm{m})\end{array}$ & $\begin{array}{c}\text { Sheet } \\
\text { Swelling } \\
\text { (\%) }\end{array}$ & $\underset{\left.\text { ( } \mathbf{g}_{\text {water }} / \mathbf{g}_{\text {fiber }}\right)}{\mathbf{A B S}}$ & 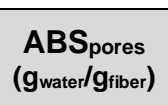 & $\begin{array}{l}\text { ABS } \\
\text { swelling } \\
\text { ( } \text { gwater }_{\text {wiber }} \text { ) }\end{array}$ & $\underset{\left.\text { ( } \mathbf{g}_{\text {water }} / \mathbf{g}_{\text {fiber }}\right)}{\mathbf{A B S}}$ \\
\hline \multirow{3}{*}{ BEK } & Unrefined & 151 & 180 & 19.5 & 6.8 & 4.3 & 1.0 & 1.5 \\
\hline & 1000 & 141 & 176 & 25.1 & 5.7 & 3.9 & 1.1 & 0.7 \\
\hline & 2000 & 131 & 162 & 24.1 & 5.4 & 3.6 & 1.0 & 0.8 \\
\hline \multirow{4}{*}{ Acacia } & Unrefined & 150 & 173 & 15.1 & 5.7 & 4.2 & 0.7 & 0.8 \\
\hline & 500 & 141 & 164 & 16.3 & 5.1 & 3.7 & 0.7 & 0.7 \\
\hline & 1000 & 131 & 151 & 15.0 & 5.0 & 3.6 & 0.6 & 0.7 \\
\hline & 2000 & 134 & 154 & 15.2 & 4.6 & 3.4 & 0.6 & 0.5 \\
\hline \multirow{3}{*}{ SBHK } & Unrefined & 176 & 202 & 14.9 & 7.0 & 5.2 & 0.9 & 1.0 \\
\hline & 1000 & 139 & 167 & 20.1 & 5.4 & 4.0 & 0.9 & 0.5 \\
\hline & 2000 & 125 & 157 & 25.5 & 5.1 & 3.5 & 1.1 & 0.5 \\
\hline \multirow{3}{*}{ NBHK } & Unrefined & 129 & 164 & 27.9 & 6.1 & 3.8 & 1.2 & 1.1 \\
\hline & 500 & 126 & 158 & 25.9 & 5.1 & 3.3 & 1.0 & 0.8 \\
\hline & 1000 & 121 & 152 & 26.3 & 4.9 & 3.1 & 1.0 & 0.8 \\
\hline
\end{tabular}

In order to determine if chemical composition could be used to explain the differences observed in water absorbency, the surface composition of the hardwood pulps was evaluated using XPS. The surface composition can be used as an indication of the surface wettability (hydrophilicity) (Hubbe et al. 2015). The surface wettability of the cellulosic fibers affects the water absorbency. Water presents a higher tendency to quickly spread and fill the spaces between fibers and to promote swelling when a tissue paper product is manufactured with cellulosic fibers that have hydrophilic surfaces (Aberson 1969).

The chemical components of cellulosic fibers (cellulose, hemicellulose, lignin, and extractives) have a distinct hydrophilicity. Cellulose and hemicellulose are known to have polar hydroxyl groups $(-\mathrm{OH})$ that can form a strong interaction with water via hydrogen bonding. In the case of cellulose and especially in the crystalline regions, the majority of hydroxyl groups are not available for interaction with water because they form intra molecular and inter chain hydrogen bonds. In contrast, the absence of structural regularity observed in the amorphous regions of cellulose and hemicelluloses increases the availability of hydroxyl groups for interaction with water molecules. Additionally, hemicelluloses have carboxylic acid groups $(-\mathrm{COOH})$ that can interact with water molecules via electrostatic effects, especially at $\mathrm{pH}$ values above 5.3, where the charged form $\left(-\mathrm{COO}^{-}\right)$is fully expressed. Lignin is a highly aromatic polymer composed of different amounts of monomeric groups (guaiacyl, syringyl, and $p$-hydroxyphenyl) that are 
bonded together by esters, ethers, $(\mathrm{C}-\mathrm{C})$, and other connections. The oxygen to carbon ratio of lignin is lower than the observed value for carbohydrates, which makes lignin less hydrophilic. Extractives are composed of a variety of hydrophobic components (e.g., fatty acids, resin acids, and triglyceride fats) that are rich in alkyl carbon $(\mathrm{C}-\mathrm{C})$ (Hubbe et al. 2013; Hubbe et al. 2015). The theoretical oxygen to carbon ratio and the amount of carbons with different degrees of oxidation can be calculated for cellulose, hemicellulose, lignin, and extractives based on empirical chemical formulas. Typically, the amount of alkyl carbon $(\mathrm{C}-\mathrm{C})$ is higher in extractives, followed by lignin and carbohydrates. Only carbon and oxygen atoms can be detected by XPS in pure cellulosic fibers, and the chemical shift of $\mathrm{C} 1 \mathrm{~s}$ can be separated into the $\mathrm{C} 1(\mathrm{C}-\mathrm{H}, \mathrm{C}-\mathrm{C}), \mathrm{C} 2(\mathrm{C}-\mathrm{O}), \mathrm{C} 3(\mathrm{C}=\mathrm{O}$ or $\mathrm{O}-\mathrm{C}-\mathrm{O})$, and $\mathrm{C} 4$ groups $(\mathrm{O}=\mathrm{C}-\mathrm{O})$. Therefore, XPS can be used to evaluate the amount of hydrophobic material (e.g., lignin and extractives) on the fiber surface, according to the amount of alkyl carbon $(\mathrm{C}-\mathrm{C})$ detected. Cellulosic fibers with a surface rich in lignin and/or extractives presents a higher amount of alkyl carbon $(\mathrm{C}-\mathrm{C})$, which is an indication of a lower wettability. In contrast, if a fiber surface is rich in carbohydrates, a lower amount of alkyl carbon (C-C) will be detected by XPS, which is an indication of a higher wettability (Laine and Stenius 1994).

Table 4 presents the elemental surface composition of the hardwoods measured with XPS. Because all of the kraft hardwood pulps evaluated were fully bleached, only trace amounts of lignin and/or extractives would be expected in the bulk chemical composition. However, the XPS results showed that there was a notable difference in the surface composition among the hardwood pulps. The SBHK pulp presented the highest oxygen to carbon ratio and subsequently a lower amount of alkyl carbon $(\mathrm{C}-\mathrm{C})$, while the acacia pulp presented the lowest oxygen to carbon ratio and a higher content of alkyl carbon.

Table 4. Elemental Surface Composition of the Hardwoods Using X-ray Photoelectron Spectroscopy.

\begin{tabular}{|c|c|c|c|c|c|}
\hline $\begin{array}{c}\text { Market } \\
\text { Pulp }\end{array}$ & O/C Ratio & C-C or C-H & C-O & C=O or O-C-O & O=C-O \\
\hline BEK & 0.78 & 21 & 59 & 20 & $<1$ \\
\hline Acacia & 0.75 & 28 & 51 & 20 & $<1$ \\
\hline SBHK & 0.84 & 19 & 60 & 22 & $<1$ \\
\hline NBHK & 0.80 & 23 & 55 & 21 & $<1$ \\
\hline
\end{tabular}

Qualitatively, the surface wettability of the hardwood pulps decreased in the following order: SBHK $>\mathrm{BEK} \approx \mathrm{NBHK}>$ acacia. Because the SBHK pulp had a distinct morphology, no conclusion was drawn about the effect of the surface composition on the differences in the water absorbency observed between the SBHK and other hardwood pulps. The BEK and NBHK pulps had similar elemental surface compositions. However, the NBHK pulp presented a higher number of fines and shorter fibers, which contributed to densification of the fiber web and subsequently lower water absorbency at low refining levels. At higher refining levels and when the bulk was below 4.5, the relationship between the bulk and water absorbency was similar for the BEK and NBHK pulps. Among all of the hardwoods, the BEK and acacia pulps presented the most similar fiber morphologies, which translated as a similar bulk before and after refining. However, there was a significant difference in the water absorbency at a given bulk and all of the refining levels. 
The differences in surface composition (wettability) between the BEK and acacia pulps can be used to explain the observed differences in the water absorbency associated with the swellability of the handsheets. Acacia pulp presented higher content of alkyl carbon than BEK pulp, which is probably associated with the concentration of extractives on the fiber surface. Neto et al. (2004) have also reported a higher surface concentration of extractives for bleached acacia kraft pulp when compared to bleached eucalyptus kraft pulp. The higher surface concentration of extractives have negatively affected the swellability and water absorbency of acacia pulp when compared to the other hardwoods.

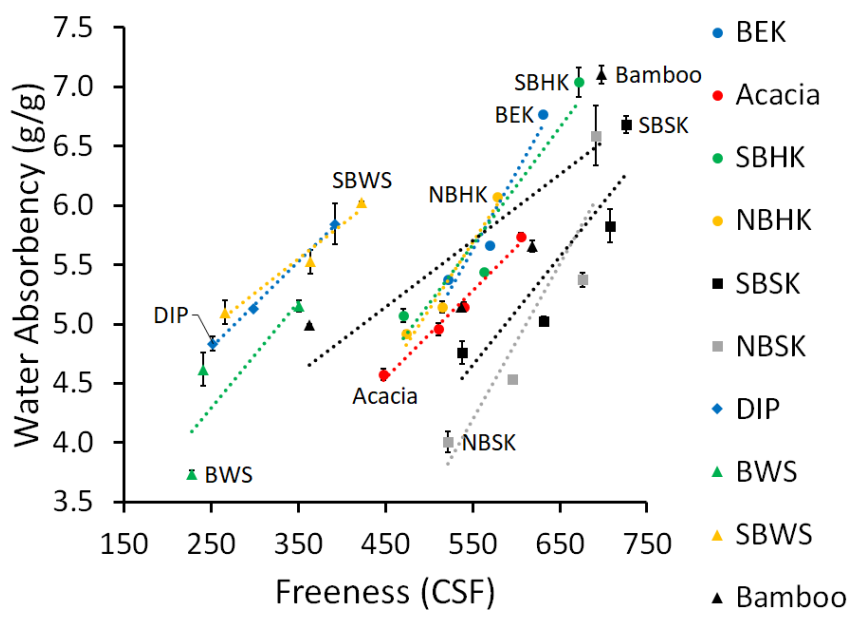

Fig. 5. Water absorbency capacity as a function of the CSF $(\mathrm{mL})$ for the hardwood, softwood, recycled, and non-wood pulps at different refining levels.

Figure 5 presents the water absorbency as a function of the freeness. Among all of the evaluated pulps, the bamboo, SBHK, BEK, SBSK, and NBSK pulps presented the highest unrefined water absorbency. At low refining levels, the BEK and SBHK pulps presented a higher water absorbency and higher freeness than the NBHK and acacia pulps. At freeness values below $600 \mathrm{~mL}$ of CSF, the water absorbency for the BEK and SBHK pulps were similar to that of the acacia and NBHK pulps. Among the softwood pulps, the water absorbency between the SBSK and NBSK pulps was similar at lower refining levels. When the freeness was below $650 \mathrm{~mL}$ of CSF, the water absorbency of the NBSK pulp decreased considerably, which was related to the observed reduction in the NBSK bulk at higher refining levels. The behavior of the bamboo pulp regarding the relationship between the water absorbency and freeness was in between the hardwood and softwood pulps. The wheat straw pulps had an intermediate to low water absorbency when compared with the other virgin pulps. The relationship between the water absorbency and freeness for the wheat straw pulps was similar to that of the DIP pulp. Among all of the pulps, the BEK, SBHK, bamboo, SBSK, and NBSK pulps had the highest unrefined water absorbency values.

\section{Tensile Strength}

The strength of paper products is typically limited by the fiber strength and interfiber bonding strength (Thorp and Kocurek 1991). In highly pressed and refined paper grades (e.g., packaging and printing), the inter-fiber bonding is well developed and the paper tensile failure involves a notable amount of fiber failure (Page 1969). Because tissue 
paper products are manufactured using low levels of wet pressing and low refining, the contact and bonding between fibers are not fully developed and the paper tensile failure is limited to a certain extent by the strength of the inter-fiber bonding. Wet pressing and refining can be used to develop the strength of tissue paper products. However, there is a tradeoff between the strength, water absorbency, and softness. Refining and wet pressing create a denser paper product with a higher strength, but lower water absorbency and softness (de Assis et al. 2018b). In this context, cellulosic fibers capable of forming strong inter-fiber bonding at low levels of pressing and refining are highly desirable for imparting strength (Nanko et al. 2005).

Figure 6 presents the results for the tensile strength, calculated as the breaking length and plotted as a function of the freeness. The tensile strength of the softwood pulps was similar at high freeness values. However, when the freeness was below $650 \mathrm{~mL}$ of CSF, the NBSK pulp became stronger than the SBSK pulp, which was explained by the faster fiber web densification and consequent higher bonding ability of the NBSK pulp compared with those of the SBSK pulp. The hardwoods had a similar unrefined strength; however, the BEK and SBHK pulps can provide a higher strength than the acacia and NBHK pulps at a given freeness. To achieve the same freeness, BEK and SBHK pulps require higher levels of refining energy resulting in superior strength at a given freeness.

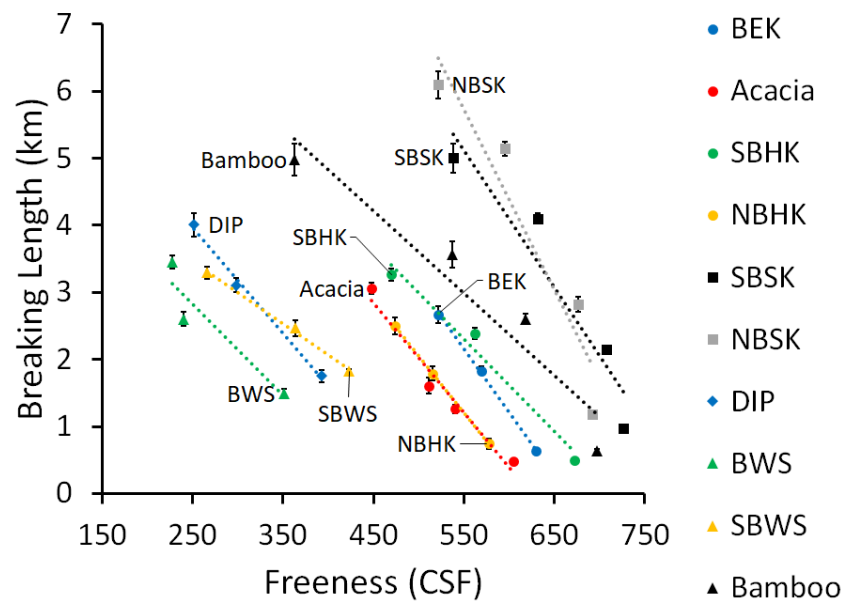

Fig. 6. Tensile strength represented as the breaking length as a function of the CSF $(\mathrm{mL})$ for the hardwood, softwood, recycled, and non-wood pulps at different refining levels.

The relationship between the tensile strength and freeness for the bamboo pulp was in between that of the hardwood and softwood pulps. The wheat straw pulps had a similar behavior as that of the recycled pulp. The wheat straw and recycled pulps had a higher unrefined strength than all of the other virgin pulps. Although it was expected that the recycling process would reduce the bonding ability of the fibers, recycled fibers have been refined previously which makes them stronger than unrefined virgin pulps (McKinney 1995).

The comparison among all of the market pulps showed that the softwood pulps can provide a higher strength at a higher freeness, followed by the bamboo and hardwood pulps. Wheat straw and recycled pulps presented the worst combination for the tensile strength and freeness. Although the strength of the recycled and wheat straw pulps can be developed, refining has to be applied with caution. Excessive refining causes breakage of the stiff recycled fibers and further increases the content of short fibers and fines (Hubbe 
et al. 2007). The use of high intensity refining with non-wood pulp (e.g., wheat straw and bamboo pulps) is known to cause disaggregation and disintegration of non-fibrous cells (e.g., parenchyma cells), which further decreases the drainage and increases the fiber web density (Subrahmanyam et al. 2000).

\section{Softness}

Softness is a complex and important property for tissue paper products, especially for bath and facial tissue paper, where product acceptance is strongly driven by the perceived softness (de Assis et al. 2018b). Softness is a sensation experienced by humans that combines several sensorial reactions, including not only the tactile feeling, but also visual and audio perceptions. Softness is typically divided into surface softness and bulk softness (Hollmark and Ampulski 2004). Short and thin fibers having low coarseness are desirable for surface softness because they form a smooth surface with a high number of flexible fiber free ends that promotes a velvet-like feeling when touched by the human fingers. Fibers that can form a bulky, flexible and easy to crumple paper web are desirable for imparting bulk softness (Nanko et al. 2005).

Softness is traditionally assessed by human panels. Valid and meaningful human panels are obtained at the expense of many resources $(e . g .$, a large number of people and tests). To minimize time and resources, many different methods and instruments have been created to assess the softness by measuring and combining different surface properties (e.g., smoothness, roughness, and fiber free ends) and bulk properties (e.g., bulk, stiffness, compressibility, and stretching). Currently, there is no method or instrument that can fully mimic the human perception of softness. However, methods that combine bulk and surface properties usually have better correlation to human panels (Hollmark and Ampulski 2004).

Figure 7 presents the results from the softness panel test as a function of freeness. Due to the high number of samples, the softness panel was divided in two parts. Because the bamboo pulp presented a morphology that is in between hardwood and softwood pulps, the first softness panel was performed to evaluate how the bamboo pulp compares with all hardwood and softwood pulps (Fig. 7a). As wheat straw pulps presented morphologies that are similar to hardwoods and recycled pulps, the second softness panel was executed to compare wheat straw pulps with SBHK and DIP pulps (Fig. 7b).

According to Figure 7, the decrease in freeness is followed by a decrease in softness score. At the same time that refining developed tissue strength, it also increased sheet density and stiffness, which contribute for the reduction of perceived softness (bulk softness). Among all hardwood pulps and at the unrefined state, acacia and BEK pulps presented the best softness, followed by NBHK and SBHK pulps. However, at higher refining levels, acacia and NBHK pulps presented better softness at a given freeness, followed by BEK and SBHK pulps. Among the softwood pulps, NBSK pulp presented better softness than SBSK pulp at all freeness levels. As expected, the perceived softness for the bamboo pulp was in between hardwood and softwood pulps. The performance of bamboo pulp was in between SBHK and NBSK pulps. At the unrefined state, the SBHK pulp presented better softness than wheat straw and DIP pulps. The wheat straw pulps offered better softness than DIP pulp at a given freeness. The bleached wheat straw pulp could provide better softness at a given freeness than the semi-bleached wheat straw pulp probably due to the differences in fiber flexibility.

The comparison among all the market pulps studied in terms of softness showed that acacia, NBHK, and BEK pulps displayed superior softness. The combination of short fibers with thin cell wall and low content of fines provided the ideal morphology for 
softness. Short and thin fibers form a flexible fiber web and a smooth surface that promote a pleasant feeling when touched by the human fingers. The SBHK, NBSK, wheat straw, and bamboo pulps could provide intermediate softness. The SBSK and DIP pulps exhibited the worst softness. Long fibers, high coarseness, high content of fines, and high fiber stiffness are the morphological features that are not desirable for tissue softness. Coarse fibers form a stiff fiber web and a rough surface that is not pleasant to human touch. High content of fines increases sheet densification and reduces perceived softness. Recycled fibers are stiff and form rigid and rough fiber webs.
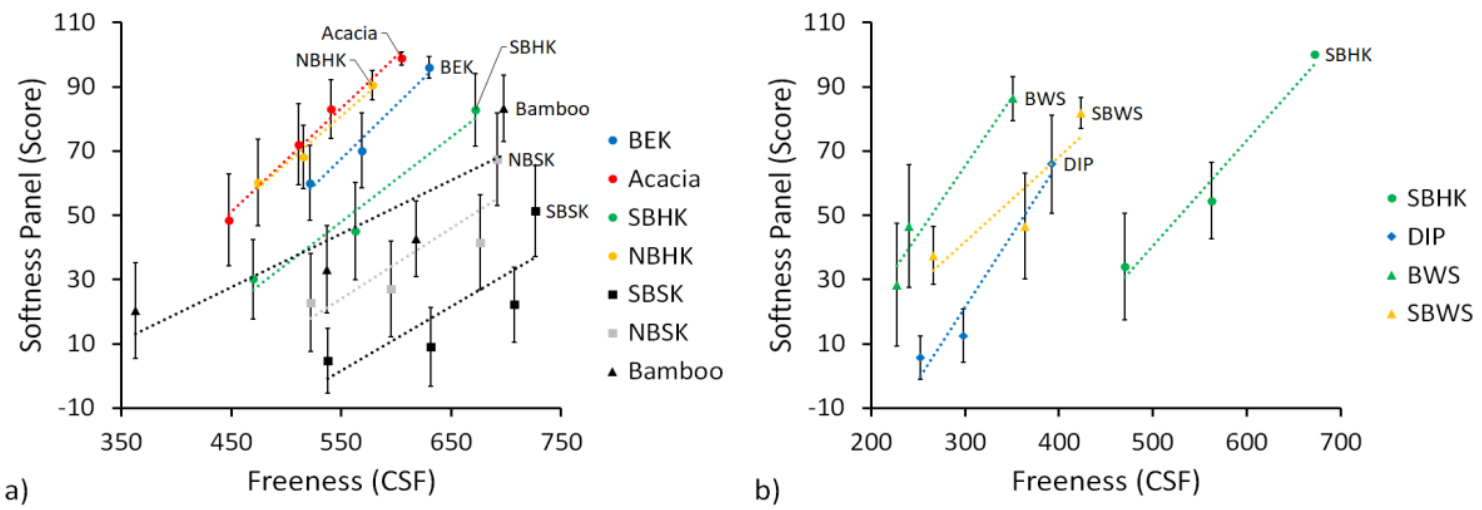

Fig. 7. Softness panel as a function of the CSF $(\mathrm{mL})$ for the hardwood, softwood, recycled, and non-wood pulps at various refining levels: (a) hardwoods, softwoods and bamboo; and (b) SBHK, DIP and wheat straw; the higher the softness score, the higher the softness.

Softness was also assessed using the TSA and Kawabata surface tester to determine if the physical properties measured by these instruments could be used to predict softness. The correlation between the softness panel and the major parameters obtained with TSA was evaluated. The degree of correlation between bulk, TS7 (TSA softness), TS750 (TSA smoothness) and $D$ (TSA stiffness) with the softness panels (Fig. 7) was low (the values for the coefficient of determination were below 0.60). In particular, the correlation between the softness panels and TS7, which is the most important parameter used by TSA to predict softness, presented very low values (coefficient of determination < 0.30). However, when each market pulp was evaluated individually, there was a strong correlation between bulk, TS7, TS750, and $D$ with the softness panel. This behavior indicated that none of these physical properties could be used to predict the softness of handsheets when different types of market pulps refined at various levels were evaluated simultaneously. However, bulk, TS7, TS750, and $D$ could be used as indicators for softness when the handsheets were prepared using the same pulp at different refining levels. Although the TSA seems to be a useful tool to predict the softness of commercial products (Wang et al. 2019), there are limitations about its use to predict the softness of handsheets. EMTEC Electronic GmbH (Germany) describes that porosity effects, surface smoothness, forming, and drying methods and microphone position are the reasons for the discrepancies in the handsheets results. It is important to mention that EMTEC recently developed an upgraded version of the TSA that is claimed to be capable of capturing the differences in softness for handsheets prepared with short and long fibers (Prinz et al. 2018).

Figure 8 presents the results from the Kawabata surface tester. The market pulps could be separated in three distinct groups according to their surface roughness or smoothness. The BEK, acacia, and NBHK pulps displayed the lowest surface roughness 
(mean deviation of caliper $\sim 1 \mu \mathrm{m}$ ). A second group of fibers (SBHK, NBSK, wheat straw, and bamboo) presented intermediate surface roughness (mean deviation of caliper $\sim 1.4$ $\mu \mathrm{m})$. The SBSK and DIP offered the highest values for mean deviation of caliper $(\sim 1.9$ $\mu \mathrm{m})$. Once again, the fiber morphology is an important factor to determine the surface roughness.

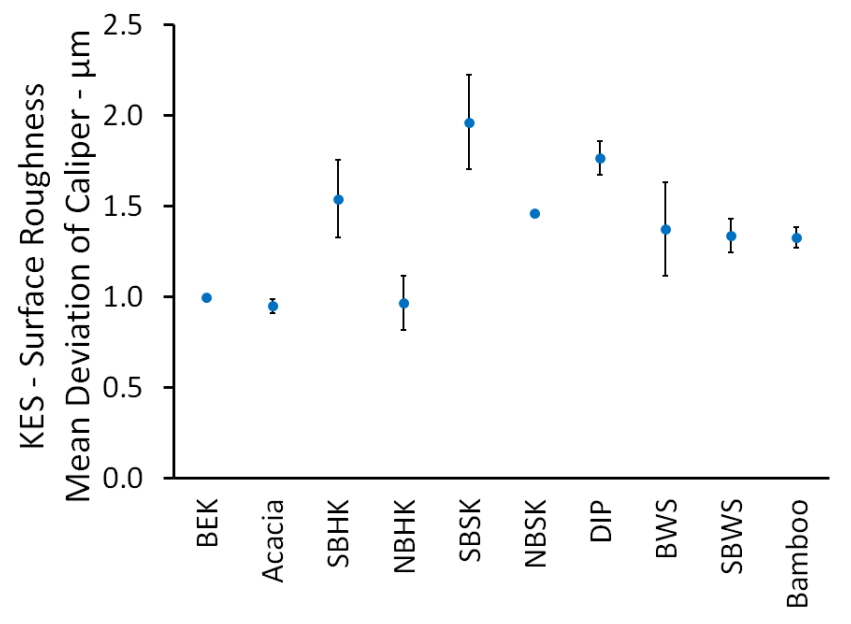

Fig. 8. KES Surface roughness of handsheets prepared with the unrefined hardwood, softwood, recycled, and non-wood pulps; the higher the roughness value, the higher the surface roughness.

For a given basis weight, surface roughness increases with the increase of sheet thickness and fiber mass. The effect of fiber mass on surface roughness can be understood by analogy to filling a bucket with small and large stones (Niskanen et al. 2008). Similarly, short and low coarseness fibers are more uniformly distributed during forming process and creates a smoother surface. On the other hand, long and coarse fibers decrease the formation uniformity resulting in a paper surface that has higher deviation of local surface height. All of the hardwood pulps presented a similar morphology, with exception of SBHK pulp. SBHK pulp had a higher length and cell wall coarseness than the BEK, acacia, and NBHK pulps. Because of its higher length and thicker cell wall, SBHK pulp presented higher surface roughness. Both softwood pulps presented similar fiber length and width. However, the SBSK pulp had a higher cell wall coarseness than the NBSK pulp, which can be used to explain the differences in surface roughness. Because of the recycling process, recycled fibers are less flexible and less conformable than virgin fibers. The lack of conformability makes DIP fibers more dimensionally stable and does not allow for the formation of a uniform and smooth surface. Bamboo and wheat straw pulps presented intermediate fiber length, coarseness, and surface roughness.

The comparison among all market pulps shows that short fibers having low width and low coarseness could provide better surface smoothness. On the other hand, long, thick, and coarse fibers presented higher surface roughness. The results obtained with the Kawabata evaluation system were in line with the softness panel presented in Fig. 7. There was a general tendency showing that market pulps that provided higher surface smoothness also presented higher score in the softness panel than the market pulps having low surface smoothness. For example, BEK, acacia, and NBHK pulps had the highest softness score at a given freeness and presented the highest surface smoothness. On the other hand, SBSK and DIP pulps had the lowest surface smoothness and lowest softness score. Finally, there 
is a group of pulps (SBHK, NBSK, wheat, and bamboo) that presented intermediate surface smoothness and intermediate softness score at a given freeness. Therefore, the surface roughness (surface softness) was a very important factor to differentiate for the perceived softness of the handsheets at a given freeness.

\section{Tradeoff among the Water Absorbency, Strength, and Softness}

The presented results showed that there were tradeoffs between the water absorbency, strength, and softness when mechanical refining was used to develop the strength of tissue paper. The refining process causes fibrillation and delamination of the fiber cell wall, which increases the wet-flexibility, collapsibility, and bonding ability of the cellulosic fibers, and improves the strength of the paper products (Hubbe et al. 2007). However, the refining process increases the density of the fiber web, reducing the volume of air spaces between fibers, which decreases the water absorbency. Additionally, the refining process negatively affects softness. Denser and stronger fiber webs have a lower flexibility and reduced softness.
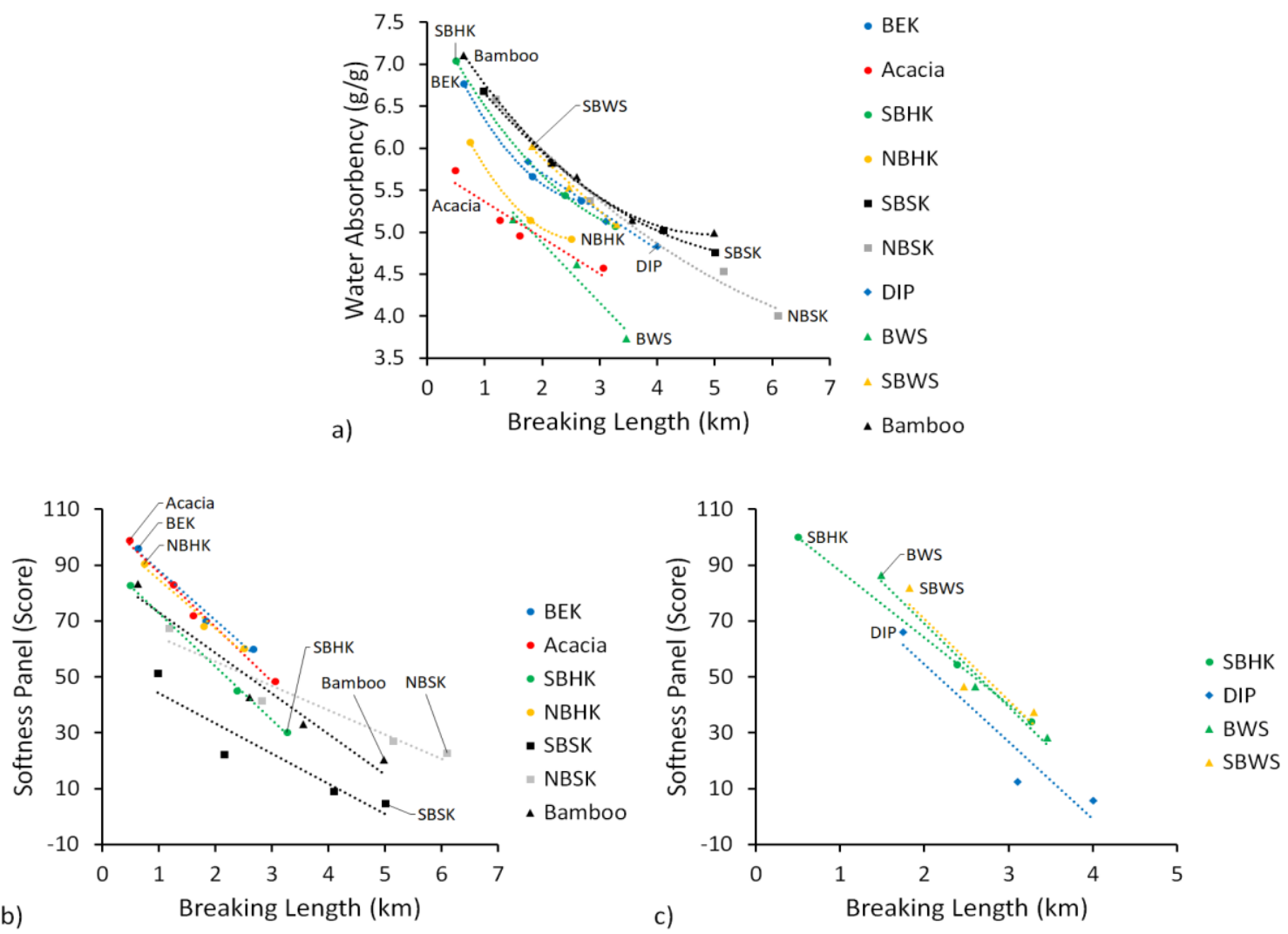

Fig. 9. Water absorbency capacity and softness panel as a function of the tensile strength (breaking length) for the hardwood, softwood, recycled, and non-wood pulps at different refining levels; (a) water absorbency capacity as a function of the breaking length; and (b) and (c) softness panel as a function of the breaking length; the higher the softness score, the higher the softness.

Therefore, during the manufacturing of tissue products, a balance between the strength, softness, and water absorbency is achieved according to the product category (e.g., bath, towel, and napkin) and desired specification. However, the value of tissue paper products inside a product category increases with an improvement in its properties. For 
example, de Assis et al. (2018a) showed that the shelf price of kitchen towels is proportional to the performance (properties). Remarkably, the water absorbency and softness have a higher effect on the tissue paper value. In this context, cellulosic fibers that can yield tissue paper products with a high water absorbency and softness at a given strength are highly desirable. To address this issue, the water absorbency and softness are presented as a function of the tensile strength in Fig. 9.

Figure 9a presents the water absorbency capacity as a function of the tensile strength. Among all of the studied pulps, the bamboo, SBHK, BEK, SBSK, and NBSK pulps resulted in the highest unrefined water absorbency. The bamboo, SBSK, and NBSK pulps provided the best combination for the tensile strength and water absorbency, followed by the SBHK and BEK pulps. The SBWS, DIP pulps can also be used to impart good strength and water absorbency. The acacia and NBHK pulps provided reasonable water absorbency at an unrefined state. However, the water absorbency at higher strength levels was low. The BWS pulp presented the worst combination of water absorbency and strength.

Figures $9 \mathrm{~b}$ and $9 \mathrm{c}$ show the softness panel as a function of the tensile strength. The acacia, BEK, and NBHK offered superior softness at a given strength among all studied pulps. The SBHK, NBSK, bamboo, and wheat straw pulps presented intermediate combination of softness and strength. The market pulps having the worst combination of softness and strength were SBSK and DIP pulps. Acacia, BEK, and NBHK provided superior softness at unrefined state, followed by SBHK and bamboo pulps.

\section{Matching the Fiber Type with Tissue Paper Products and Grades}

The value or price of tissue paper products is mostly related to the performance or properties. The target or essential properties for a defined product category change according to its application (e.g., bath tissue, facial tissue, napkin, and towel). Typically, the essential properties for bath and facial tissues are, in order of importance, the softness, water absorbency, and strength. In contrast, napkin and towel products require high levels of water absorbency and strength (Novotny 1988; Zou 2017a). Additionally, different product grades (e.g., economy, premium, and ultra) inside a specific product category require different performance levels. Economy products have a low performance and are manufactured with a high content of recycled and low-quality fibers. Premium products are manufactured with a lower amount of recycled fibers. Ultra products have a high quality and are manufactured with a high content of virgin and high-quality fibers, using a minimum content of recycled fibers (de Assis et al. 2018b). In this context, a discussion that links the fiber morphology, tissue properties, and tissue products was provided. The authors indicated what pulp type would be more suitable for an application in a specific product category and grade based on the observed fiber morphology and tissue paper properties.

BEK, SBHK, SBSK, NBSK, and bamboo pulps are adequate for high quality (premium and ultra) napkin and towel products because they offered superior combination of water absorbency and strength. At low refining levels, the SBHK and bamboo pulps could be used to impart better water absorbency than BEK, SBSK, and NBSK pulps. At higher refining levels, the SBSK, NBSK, and bamboo pulps could deliver higher water absorbency than BEK and SBHK pulps at a given strength. SBSK, NBSK and bamboo pulps have long fibers with high coarseness that can provide superior combination of strength, bulk and absorbency when compared to the shorter and thinner fibers present in BEK and SBHK pulps. SBWS and DIP pulps could be used in low quality (economy) 
napkin and towel products because they had an intermediate combination of water absorbency and strength. SBWS and DIP pulps have intermediate fiber length and coarseness, however, with very high content of fines that promotes densification of the fiber web resulting in lower bulk and water absorbency. Acacia and NBHK pulps could be used in napkin and towel products that require a lower water absorbency and higher softness. Acacia and NBHK pulps have the lowest fiber length and coarseness among all fibers evaluated. The BWS pulp exhibited the worst combination of water absorbency and strength. BWS pulp presented the highest content of fines and lowest bulk among all fibers.

Acacia, BEK, and NBHK pulps are recommended for high quality (premium and ultra) bath and facial products, in which high levels of softness are required. Acacia, BEK and NBHK are short and thin fiber having low coarseness. BEK pulp is especially desired because it provides superior water absorbency when compared to acacia and NBHK pulps. At the unrefined state, acacia pulp presented better softness, followed by BEK and NBHK pulps. A low level of refining is recommended for these hardwoods to avoid loss of softness. Bamboo and NBSK pulps contain long fibers with intermediate coarseness that could be used in conjunction with the hardwood pulps to provide strength without significantly sacrificing softness and water absorbency. The SBHK and the wheat straw pulps, which have intermediate fiber length and coarseness, can be used in economy products as they provide intermediate combination of softness and strength. SBSK and DIP pulps presented the worst combination of softness and strength. Long and coarse fibers present in SBSK pulp are not desirable for softness. DIP fibers are stiff and do not provide good softness.

The comparison between the wood, non-wood, and recycled pulps showed that bamboo pulp can replace hardwood and softwood pulps in an unrefined state to provide superior water absorbency. At higher refining levels, bamboo pulp can be used to replace the softwood pulps to provide similar water absorbency at a given strength. At the unrefined state, bamboo pulp can also be used to replace SBHK pulp to achieve similar softness. At higher refining levels, bamboo, SBHK, and NBSK pulps can achieve similar combination of softness and strength. Wheat straw pulps presented similar combination of softness and strength as the SBHK and NBSK pulps at higher refining levels, but lower softness than SBHK pulp at the unrefined state. Wheat straw pulps can also be used to replaced DIP pulp in applications were intermediate levels of water absorbency and strength are desired.

Pulp blending and mechanical refining can be explored to maximize the performance of different products. For example, unrefined BEK or NBHK pulps can be blended with refined bamboo and NBSK pulps to maximize the water absorbency and softness without sacrificing the strength.

\section{Final Considerations and Limitations}

Caution has to be taken in future studies aimed at extrapolating the data generated in this study for actual industrial products; however, the results can be used as a starting point to understand the potential of different fibers for tissue applications. The data presented here were based on uncreped handsheets made on a laboratory scale without the use of any chemical additives. It is well known that, in addition to the fiber type, the machine technology (e.g., wet pressing, thorough-air drying (TAD), creping, and layering) and chemical additives (e.g., dry strength additives, wet strength additives, and softeners) have a notable impact on the final properties of the tissue products and manufacturing process (de Assis et al. 2018b). 
The creping process is a very important process step used to enhance bulk, water absorbency, softness, and stretch of tissue paper products. Additionally, different fiber types will respond differently to the creping process. In any case, the results obtained for tensile strength and water absorbency with the uncreped handsheets seem to be in line with the results that would be obtained if the same pulps were used to manufacture creped tissue products. For example, long fibers having thin cell wall, such as NBSK pulp, are very desirable as a source of strength for tissue paper manufacturing, while long fibers having high coarseness to width ratio, such as SBSK and bamboo pulps, can form a bulky and water absorbent tissue paper web (de Assis et al. 2018b). The results obtained for softness with the uncreped handsheets also presented a good agreement with what would be expected in creped tissue products. The literature reports that hardwood pulps are commonly used to provide superior softness for tissue paper products. For example, short fibers having thin cell wall can be used to provide a large number of free and flexible fiber ends to enhance surface softness, especially after the creping process. On the other hand, fibers that can form a bulky and flexible fiber web (e.g., softwood pulps) can provide good bulk softness (de Assis et al. 2018b). The effect of creping on tissue paper properties will be studied in a future work, where a comparison between creped and uncreped handsheets made with different market pulps will be evaluated.

The choice for a specific market pulp or pulp blend has to take into consideration not only the product performance but also product appearance. Brightness is an important factor for positioning tissue products according to the target market segment (e.g. consumer, away from home), product type (e.g. bath tissue, towel, facial tissue), and product category (e.g. economy, premium, ultra). In this context, comparisons amongst fibers with different brightness has limitations. The bleaching process not only affects product appearance but also changes fiber performance. Additionally, the manufacturing process also may impact the selection of a specific market pulp or pulp blend. Conventional dry-crepe machines can make products using $100 \%$ eucalyptus fibers, whereas a TAD machine and structure products require $10 \%$ to $20 \%$ of lightly refined softwood to generate enough tear propagation resistance to allow reliable paper machine and converting operations. Additionally, TAD machines by design require fibers with a high permeability and cannot use large amounts of low freeness materials, such as recycled and non-wood fibers. Finally, whether a tissue machine is layered or not influences the fiber choices and percentages used.

Specific market pulps, such as BEK, cannot be treated as a commodity for tissue paper manufacturing. Market pulps manufactured in different locations and using different species may present different performances. For example, Eucalyptus grandiflora has been hybridized with E. urophila, E. saligna, and other species to produce trees in the central coastal region of Brazil that are suitable for providing superior softness for facial tissue paper products, especially when the fibers are layered on the surface of the tissue paper. $E$. globulus and E. grandiflora produced in the southern region of Brazil are more suitable for printing and writing paper grades, even though they are also used in tissue products. Iberian Eucalyptus globulus pulp is manufactured using trees that are older than the trees harvested in Brazil. Many eucalyptus trees in Portugal and Spain are not harvested before they are 20 years to 24 years old. Fibers obtained from old trees present a lower uniformity, thicker cell walls, higher length, and higher diameter. Iberian eucalyptus is suitable for printing and writing grades, and it has been found to be unsatisfactory for layering on the surface of facial tissue paper. However, Iberian eucalyptus works well as a bulk fiber for bath tissue and napkin products (Nanko et al. 2005). 


\section{CONCLUSIONS}

1. In this study, a comparison among wood, non-wood, and recycled pulps at a laboratory scale using uncreped handsheets was performed to evaluate which market pulps are more suitable for different tissue paper products and to evaluate what fiber features are desired for a specific tissue property. Additionally, the market pulps were mechanically refined at different levels to evaluate the effect of refining action on the strength, softness, and water absorbency. The results showed that the strength was inversely related to the softness and water absorbency. Fibrillation of the fiber surface and delamination of the fiber cell wall caused by the refining process increased the wet flexibility, collapsibility, and bonding ability of the individual fibers, which increased the strength of the fiber web. However, increasing the strength was accompanied by a densification of the fiber web, which reduced the water absorbency and softness.

2. The results showed that the fiber morphology has a major impact on the observed tissue paper properties. Market pulps with a combination of long fibers, high coarseness, and low fines content can provide superior bulk and water absorbency. Long fibers having thin cell wall can be used to impart strength without sacrificing softness significantly. Short fibers with low coarseness and low fines content can provide superior softness.

3. The BEK, SBHK, SBSK, NBSK, and bamboo pulps are adequate for premium napkin and towel products because they can impart superior combination of water absorbency and strength. Acacia, BEK, NBHK, NBSK, and bamboo pulps are recommended for premium bath and facial products, in which high levels of softness are required. The DIP and wheat straw soda pulps can be used in economy towel products. SBHK, NBSK, DIP, wheat straw, and bamboo pulps can be used in economy bath tissue.

4. Bamboo pulp can replace BEK, SBHK, SBSK, and NBSK to provide excellent combination of water absorbency and strength. Bamboo pulp can also be used to replace NBSK to provide strength without sacrificing softness. Wheat straw pulp can replace SBHK and DIP pulp in application were intermediate water absorbency and softness are required.

\section{ACKNOWLEDGMENTS}

This work was financially supported by Tissue Pack Innovation Lab (North Carolina State University, College of Natural Resources, Department of Forest Biomaterials). Special acknowledgment for the graduate students at the Department of Forest Biomaterials - North Carolina State University for helping with the softness panel.

\section{REFERENCES CITED}

Aberson, G. M. (1969). "The water absorbency of pads of dry, unbonded fibers," TAPPI STAP 8, 282-305.

Axelsson, B. (2001). "Pulp for high absorption tissue products," Paper Technology 42(7), 24-26.

Beuther, P. D., Veith, M. W., and Zwick, K. J. (2010). "Characterization of absorbent 
flow rate in towel and tissue," J. Eng. Fiber. Fabr. 5(2), 1-7.

Byrd, M., and Hurter, R. (2013). "Considerations for the use of nonwood raw materials for tissue manufacture," in: PaperCon 2013, Atlanta, GA.

Cao, S., Ma, X., Lin, L., Huang, F., Huang, L., and Chen, L. (2014). "Morphological and chemical characterization of green bamboo (Dendrocalamopsis oldhami (Munro)

Keng f.) for dissolving pulp production," BioResources 9(3), 4528-4539.

DOI: 10.15376/biores.9.3.4528-4539

de Assis, T., Reisinger, L., Dasmohapatra, S., Pawlak, J., Jameel, H., Pal, L., Kavalew, D., and Gonzalez, R. (2018a). "Performance and sustainability $v s$. the shelf price of tissue paper kitchen towels," BioResources 13(3), 6868-6892. DOI:

10.15376/biores.13.3.6868-6892

de Assis, T., Reisinger, L., Pal, L., Pawlak, J., Jameel, H., and Gonzalez, R. W. (2018b). "Understanding the effect of machine technology and cellulosic fibers on tissue properties - A review," BioResources 13(2), 4593-4629.

DOI: $10.15376 /$ biores.13.2.4593-4629

Essity (2017). "Year-end report 2017," (http://essity.videosync.fi/2018-0125_q4?seek=830), Accessed 13 Apr 2018.

Euromonitor (2017). "Market size of tissue products," (https://www.euromonitor.com/usa), Accessed on 01/07/2017.

FAO (2017). "Forestry production and trade," (http://www.fao.org/faostat/en/\#data/FO), Accessed on 01/07/2017.

Fisher International (2018). "FisherSolve," (https://www.fisheri.com/productsservices/fishersolve/), Accessed 01/12/2018.

Foelkel, C. (2007). "Advances in eucalyptus fiber properties \& paper products," International Colloquium on Eucalytus Pulp, (http://www.celsofoelkel.com.br/artigos/outros/Advances in euca fiber.pdf), Accessed 01/02/2018.

Gigac, J., and Fišerová, M. (2008). 'Influence of pulp refining on tissue paper properties," Tappi J. 7(8), 27-32.

Goel, A., Jewell, M., Tschirner, U., and Ramaswamy, S. (2000). "Comparison of refining of soda AQ and organosolv wheat straw pulps with traditional wood pulps," in: TAPPI Pulping/Process \& Product Quality Conference Proceedings, Boston, MA.

Grüner, A. (2016). "TSA - Tissue softness analyzer," in: PaperCon 2016, Cincinnati, $\mathrm{OH}$.

Hall, C. (1983). “Eucalyptus pulp for tissue,” Paper (London) 200(9), 32-36.

Hollmark, H., and Ampulski, R. S. (2004). "Measurement of tissue paper softness : A literature review," Nord. Pulp. Pap. Res. J. 19(3), 345-353. DOI: 10.3183/NPPRJ2004-19-03-p345-353

Hubbe, M. A. (2006). "Bonding between cellulosic fibers in the absence and presence of dry-strength agents - A review," BioResources 1(2), 281-318.

DOI: 10.15376/biores.1.2.281-318

Hubbe, M. A., Venditti, R. A., and Rojas, O. J. (2007). "What happens to cellulosic fibers during papermaking and recycling? A review," BioResources 2(4), 739-788.

DOI: 10.15376/biores.2.4.739-788

Hubbe, M. A., Ayoub, A., Daystar, J. S., Venditti, R. A., and Pawlak, J. J. (2013).

"Enhanced absorbent products incorporating cellulose and its derivatives: A review," BioResources 8(4), 6556-6629. DOI: 10.15376/biores.8.4.6556-6629 
Hubbe, M. A., Gardner, D. J., and Shen, W. (2015). "Contact angles and wettability of cellulosic surfaces: A review of proposed mechanisms and test strategies," BioResources 10(4), 8657-8749. DOI: 10.15376/biores.10.4.8657-8749

ISO 12625-4 (2005). "Tissue paper and tissue products - Part 4: Determination of tensile strength, stretch at break and tensile energy absorption," Internationl Organization for Standardization, Geneva, Switzerland.

ISO 12625-8 (2010). "Tissue paper and tissue products - Part 8: Water-absorption time and water-absorption capacity, basket immersion test method," International Organization for Standardization, Geneva, Switzerland.

Johnsson, G. E. (1978). "Mechanical pulp in tissues, fine papers, and boards," Paper Age 14(5), 14-15, 23-24, 31-34.

Ko, Y. C., Lee, J. H., Kim, H. J., and Sung, Y. K. (2016a). "The fundamental absorbency mechanisms of hygiene paper," Journal of Korea TAPPI 48(5), 85-97.

DOI: 10.7584/JKTAPPI.2016.10.48.5.85

Ko, Y. C., and Park, J. M. (2016b). "Developing objective linear scale data from subjective tests for consumer products", Journal of Korea TAPPI 48(1), 19-26. DOI: 10.7584/ktappi.2016.48.1.019

Kullander, J. (2012). Evaluation of Furnishes for Tissue Manufacturing, Master's Thesis, Karlstad University, Karlstad, Sweden.

Kullander, J., Nilsson, L., and Barbier, C. (2012). "Evaluation of furnishes for tissue manufacturing; Suction box dewatering and paper testing," Nord. Pulp. Pap. Res. J. 27(1), 143-150. DOI: 10.3183/npprj-2012-27-01-p143-150

Laine, J., and Stenius, P. (1994). "Surface characterization of unbleached kraft pulps by means of ESCA," Cellulose 1, 145-160. DOI: 10.1007/BF00819664

McKinney, R. W. J. (1995). Technology of Paper Recycling (First), Blackie Academic \& Professional, London, UK.

Muller, G. A., and Teufel, G. (1973). "The use of reclaimed fibre in tissue manufacture," Paper Technology 14(3/4), T146-T149.

Nanko, H., Button, A., Hillman, D., and Swann, C. E. (2005). The World of Market Pulp, WOMP, Appleton, WI.

Neto, C. P., Silvestre, A. J. D., Evtuguin, D. V., Freire, C. S. R., Pinto, P. C. R., Santiago, A. S., and Holmbom, B. (2004). "Bulk and surface composition of ECF bleached hardwood kraft fibres," Nord. Pulp. Pap. Res. J. 19(4), 513-520.

DOI: 10.3183/NPPRJ-2004-19-04-p513-520

Niskanen, K., Alava, M., Kajanto, I., Ketoja, J., Kettle, J., Pakarinen, P., Pauler, N., and Sirvio, J. (2008). Paper Physics, Finish Paper Engineer's Association/Paperi ja Puu Oy, Helsinki, Finland.

Norwegian Pulp and Paper Research Institue (1983). "More mechanical pulp in modern soft tissue," Norsk Skogind. 37(7/8), 18-19.

Novotny, R. J. (1988). "Mechanical and chemical methods enhance tissue sheet properties," Pulp Pap.-Canada 62(8), 74-78.

Page, D. H. (1969). "A theory for the tensile strength of paper," Tappi J. 52(4), 674-681.

Palmer, B., Kerr, I., Clarke, C., and Ngobese, J., (2009). Comparative refining characteristics of northern and southern hemisphere bleached softwood kraft species, Master's Thesis, University of Kwazulu-Natal, Durban, South Africa.

Pavan, P. C. (2011). "Tailoring eucalyptus fibre for tissue paper production," in: $5^{\text {th }}$ International Colloquium on Eucalyptus Pulp, Porto Seguro, Brazil.

Prinz, M., Zollner-Croll, H., Meltzer, F., and Gruner, G. (2018). 'New opportunities to 
evaluate the hand feel (HF) potential of fibre resources," in: Tissue World 2018, Bangkok, Thailand.

Siewert, W. H. (1988). "The use of waste paper in tissue production," in: TAPPI Pulping Conference, New Orleans, LA, pp. 655-659.

Singh, S., Dutt, D., and Tyagi, C. H. (2011). "Complete characterization of wheat straw (Triticum aestivum PBW-343 L. Emend. Fiori \& Paul.) - A renewable source of fibres for pulp and paper making," BioResources 6(1), 154-177.

DOI: $10.15376 /$ biores.6.1.154-177

Subrahmanyam, S. V., Godiyal, R. D., Sharma, A. K., Vipul, J. T., and Gupta, H. K. (2000). "Effect of refining energy on the pulp properties of nonwoods," IPPTA 12, 11-18.

Sundholm, J., and Huostila, M. (1980). "Can TMP and CTMP be used in tissue paper," Pulp Pap.-Canada 81(3), 60-62, 64, 67-68.

TAPPI T 205 sp-02 (2006). "Forming handsheets for physical tests of pulp," TAPPI, Press, Atlanta, GA.

TAPPI T 227 om-99 (1999). "Freeness of pulp (Canadian standard method)," TAPPI Press, Atlanta, GA.

TAPPI T 248 sp-00 (2000). “Laboratory beating of pulp,” TAPPI Press, Atlanta, GA.

TAPPI T 410 om-08 (2013). "Grammage of paper and paperboard (weight per unit area)," TAPPI Press, Atlanta, GA.

TAPPI T 580 pm-12 (2012). "Thickness (caliper) of towel, tissue, napkin and facial products," TAPPI Press, Atlanta, GA.

TAPPI T402 sp-08 (2013). "Standard conditioning and testing atmospheres for paper, board, pulp handsheets, and related products," TAPPI Press, Atlanta, GA.

Terlep, S. (2018). "Kimberly-Clark to cut 5000 jobs, close 10 factories," The Wall Street Journal, (https://www.wsj.com/articles/kimberly-clark-to-cut-5-000-jobs-close-10factories-1516710600), Accessed on 01/07/2018.

Thorp, B. A., and Kocurek, M. J. (1991). Pulp and Paper Manufacture - Volume 7: Paper Machine Operations ( $3^{\text {rd }}$ Edition), M. J. Kocurek (ed.), Joint Textbook Committee of the Paper Industry, Atlanta, GA.

Trepanier, R. J. (2017). "Pulp fiber quality and the relationship with paper tissue properties," in: Tissue2017, Miami, FL, pp. 1-30.

Tutuş, A., Özdemir, A., and Çiçekler, M. (2017). "Evaluation of linter cellulose as an alternative raw material for tissue paper production," Drvna Ind. 68(4), 291-298. DOI: $10.5552 /$ drind.2017.1647

Wang, Y., de Assis, T., Zambrano, F., Pal, L., Venditti, R. A., Dasmohapatra, S., Pawlak, J. J., and Gonzalez, R. (2019). "Relationship between human perception of softness and instrument measurements," BioResources 14(1), 780-795.

Watson, P., and Janssen, W. (2014). "High quality NBSK fibre for premium tissue paper grades," Tissue World Magazine, (http://www.tissueworldmagazine.com/featuredslider/high-quality-nbsk-fibre-for-premium-tissue-paper-grades/), Accessed on 01/02/2018.

Yuan, Z., Jong, J., and Larivière, S. (2016). "High-yield pulp in tissue and towel," in: PaperCon 2016, Cincinnati, OH.

Zou, X. (2017a). "Overview of tissue grades and their pulp furnish selection," in: PaperCon 2017, Minneapolis, MN, pp. 1-28.

Zou, X. (2017b). "Refining of HW and SW kraft for tissue making," in: PaperCon 2017, Minneapolis, MN. 
Zou, X., and Liu, H. (2016). "Review of non-wood fibres and their applications in tissue," in: PaperCon 2016, Cincinnati, OH.

Article submitted: September 27, 2018; Peer review completed: May 25, 2019; Revised version received: June 25, 2019; Accepted: June 27, 2019; Published: July 8, 2019. DOI: 10.15376/biores.14.3.6781-6810

Erratum: July 11, 2019, the figure captions of Fig. 7 (b) and Fig. 9 (c) were changed to read the higher the softness score, the higher the softness. 